\title{
Respectable Citizens: Civic Militias, Local Patriotism, and Social Order in Late Habsburg Austria $(1890-1920)^{\star}$
}

\author{
Claire Morelon \\ Department of Historical and Geographical Sciences and the Ancient World, \\ University of Padova; Padova, Italy
}

\begin{abstract}
This article analyzes the role of urban civic militias (burgher corps) in Habsburg Austria from the end of the nineteenth century to the aftermath of World War I. Far from a remnant of the early modern past, by the turn of the twentieth century these militias were thriving local institutions. They fostered dynastic patriotism and participated in the growing promotion of shooting among the population in the lead-up to the conflict. But they also played a major role in upholding the bourgeois ideals of protection of social hierarchies and property. In the context of the rise of the workers' movement and social unrest, the militias saw themselves as bulwarks of social order and bastions of bourgeois virtue. They reflected an exclusive conception of armed citizenship opposed to the egalitarian notion of the citizen-soldier that survived into the twentieth century. The sensory experience of burgher corps parades during the patriotic or church celebrations was supposed to convey stability and express hierarchies in the urban space. This article also links the practices of armed civilians before the war to the paramilitary groups that emerged in 1918 and emphasizes the legacy of local conceptions of armed defense of property and of notions of "good" citizenship in the aftermath of the war.
\end{abstract}

Keywords: Austria-Hungary, Habsburg Empire, militias, paramilitarism, citizenship, bourgeoisie/ Bürgertum, shooting associations, national guards, World War I, civic defense

It is not only in the regional capitals, but also in all the provincial towns and even the market towns of small significance that we find sharpshooting corps (Schützencorps). Their size varies, as does their organization .... The general duty of every citizen to uphold public order, peace and safety in the absence of the military made the burgher corps necessary in times past, and justifies their continued existence today .... It cannot be denied that the burgher corps of our times strive ever

\footnotetext{
${ }^{\star}$ Research for this article was supported by the European Research Council (ERC) under the European Union's Horizon 2020 research and innovation program (G.A. 677199 - ERCStG2015 “The Dark Side of the Belle Époque: Political Violence and Armed Associations before the First World War"). The author would like to thank the entire project team at the University of Padova for their feedback on successive drafts, and especially Matteo Millan. The author would also like to thank Laurence Cole for his comments on an earlier version of this text, Rudolf Kučera and the participants of our ASEEES panel, as well as the participants of the "Globalising and Localising the Great War" Oxford seminar for their useful remarks and suggestions.
}

Austrian History Yearbook 51 (2020): 193-219 @ The Author(s), 2020. Published by Cambridge University Press. This is an Open Access article, distributed under the terms of the Creative Commons Attribution licence (http://creative commons.org/licenses/by/4.0/), which permits unrestricted re-use, distribution, and reproduction in any medium, provided the original work is properly cited.

doi:10.1017/S0067237820000156 
more to fulfil their purpose and endeavor to train earnestly for their honorable activity. This is why we have seen an increasing flourishing of the existing burgher corps, and a re-creation of those that had died out. ${ }^{1}$

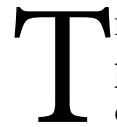

His introduction to the rules of conduct of a small-town Bohemian civic militia presents uniformed armed guards as thriving institutions in Habsburg Austria at the end of the nineteenth century. It suggests, however, that their importance was not based on their military defensive capacity, but on their role in maintaining "peace and order."

Civic guards in parade uniforms, which still exist in some Czech and Austrian towns, all trace their origins back to the Middle Ages or the early modern period. Despite their own insistence on tradition and their deep historical roots, they remained very active institutions in the modern age and were still developing all over Cisleithania at the turn of the twentieth century. This particular growth in a long period of peace might seem paradoxical, but this article argues that, despite having been dismissed as "folklore associations" living a "shadow existence" after $1848,{ }^{2}$ these associations played an important role in embodying conceptions of (local and imperial) patriotism, citizenship, and social order in small and medium-sized towns up to the eve of World War I, and even beyond. Focusing only on their military efficiency obscures their social function as bastions of bourgeois values. In an age of military conscription (introduced in 1868 in Austria-Hungary), the militias were indeed considered obsolete as defense units and were integrated into the military reserve. They shared many traits with the veterans' associations studied by Laurence Cole in their role as bearers of state patriotism and popular militarism. ${ }^{3}$ Their significance might, however, lie elsewhere: the key role they played at the local level can provide insights into what being a "good citizen" meant at the beginning of the twentieth century. ${ }^{4}$ In an age of increasing democratization and participation in politics, particularly around the battles to extend suffrage, the reactivation of former modes of civic participation was never simply about the maintenance as such of tradition. ${ }^{5}$ Suffrage reforms at the turn of the century, which culminated with the introduction of universal male suffrage for parliamentary elections in 1907, enlarged the voting base at the imperial level and, to a lesser extent, at the local level. ${ }^{6}$ Debates about the widening of the electorate encountered resistance from those who conceived of citizenship as linked to property ownership. From their role in the 1848 revolution to World War I, the civic militias participated in this defense of an exclusive local citizenship.

\footnotetext{
${ }^{1}$ Verhaltungsregeln des kaiserlich königlich privil. Scharfschützen-Corps zu Böhmisch Kamnitz (Česká Kamenice, $1880), 1$.

${ }^{2}$ Günther Kronenbitter, "Waffenträger im Vielvölkerreich-Miliz und Volksbewaffnung in der späten Habsburgermonarchie," in Spießer, Patrioten, Revolutionäre: Militärische Mobilisierung und Gesellschaftliche Ordnung in der Neuzeit, eds. Rüdiger Bergien and Ralf Pröve (Göttingen, 2010), 67.

${ }^{3}$ See Laurence Cole, Military Culture and Popular Patriotism in Late Imperial Austria (Oxford, 2014); on this argument about militias' irrelevance in the period 1870-1914, see Danielle Domergue-Cloarec and Jean-François Muracciole, eds., Les Milices du XVIe siècle à nos jours: entre construction et destruction de l'Etat? (Paris, 2010$), 14$.

${ }^{4}$ On moral definitions of citizenship in the nineteenth century, see Frank Prochaska, Schools of Citizenship: Charity and Civic Virtue (London, 2002).

${ }^{5} \mathrm{On}$ the centrality of the civic values related to the defense of the urban community's common good in early nineteenth-century Germany, see Ralf Pröve, Stadtgemeindlicher Republikanismus und die "Macht des Volkes": Civile Ordnungsformationen und kommunale Leitbilder politischer Partizipation in den deutschen Staaten vom Ende des 18. bis zur Mitte des 19. Jahrhunderts (Göttingen, 2000).

${ }^{6}$ On the battles for suffrage and the significance of 1907 in Austrian history, see: Jakub S. Beneš, Workers and Nationalism: Czech and German Social Democracy in Habsburg Austria, 1890-1918 (Oxford, 2016); John Boyer, "Power, Partisanship, and the Grid of Democratic Politics: 1907 as the Pivot Point of Modern Austrian History," Austrian History Yearbook 44 (2013): 148-74.
} 
This article, through its central focus on the immediate prewar years, aims to link the various forms of civilians in arms in Habsburg Central Europe, from the National Guards of 1848 to the post-World War I paramilitary groups. The scholarship on irregular troops after 1918 tends to view them as a product of the war conditions, analyzing the violence they perpetrated and their political radicalization. Robert Gerwarth's analysis emphasizes, for instance, the mobilizing power of military defeat and counterrevolution. ${ }^{7}$ In this article, I trace the concept of armed citizenry back to the time of the monarchy to examine the ideological foundations of prewar civic militias and the role they played at the local level. The notion of civilians taking up arms to defend the homeland had been an important feature of various associations before 1914, from shooting clubs to gymnastics associations. The militias examined here conceived themselves as bulwarks of social order fulfilling a civic duty in a context of growing social upheaval. The notion of order underpinned much of their discourse: it reflected both the simple fact of maintaining law and order and protecting private property, but also a belief, particularly important in the Austro-Hungarian context, in a strict hierarchical division of society that needed to be defended. The rise of Social Democracy constituted a direct threat to this status quo. Civic militias embodied a manly bourgeois defense of the town, which guaranteed stability and immutability. The groups that emerged after 1918 to maintain order were shaped by very immediate concerns for order in times of uncertainty, but also by prewar models.

The article begins with an overview of militias in the monarchy, their role in promoting shooting among the population, and their links with state patriotism. The second section focuses on the militias as an expression of bourgeois respectability, reflecting fears of the internal enemy during this period. The third section examines their rituals, and how the order and visual spectacle of celebrations mirrored social hierarchies in the urban space. Finally, the last section pursues the analysis into the period of World War I and its aftermath.

\section{Shooting and Patriotism}

Civic militias were not a product of the nineteenth century, but drew on older traditions of urban defense systems. Their legal status until World War I was defined by an imperial patent from 1851, which dissolved the National Guard but tolerated some forms of civic militias (the Bürgercorps), allowing them to collectively bear arms. ${ }^{8}$ However, the turn-ofthe-century militias differed widely in size, makeup, and even name across the monarchy. The largest comprised almost 350 men (in Prague), but in smaller towns they sometimes numbered not more than a few dozen. Sometimes called Bürgerkorps (burgher or civic corps) or Schützenkorps (shooting corps), elsewhere they were named Bürgergarde (civic guard) or Scharfschützenkorps (sharpshooting corps), not to mention the Czech variations, střelecký sbor, měštanský sbor, and sbor ostrostřelcü. For convenience, I will use the term "burgher corps" to refer to those formations enjoying the legal status of Bürger- und Schützenkorps,

\footnotetext{
${ }^{7}$ Robert Gerwarth, The Vanquished: Why the First World War Failed to End, 1917-1923 (London, 2016). Robert Gerwarth and John Horne, eds., War in Peace: Paramilitary Violence in Europe after the Great War (Oxford, 2012); Robert Gerwarth and John Horne, "Vectors of Violence: Paramilitarism in Europe after the Great War, 1917-1923," The Journal of Modern History 83 (2011): 489-512; Robert Gerwarth, "The Central European Counter-Revolution: Paramilitary Violence in Germany, Austria and Hungary after the Great War," Past \& Present 200 (2008): 175-209.

${ }^{8}$ Kaiserliches Patent vom 22. Aug. 1851, Allgemeines Reichsgesetz- und Regierungsblatt, 191, 531-33.
} 
setting them apart from regular shooting clubs (regulated by the 1867 law of association), which also proliferated after the turn of the century.

Their origins lay in the home defense of the medieval and early modern towns of Central Europe, which mobilized the inhabitants of a given province to defend their region in times of war. With the establishment of a standing army, however, they gradually lost their relevance as military defense formations and became increasingly subordinate to the regular army. In many cases, the Napoleonic wars constitute their last period of military engagement against enemy troops. The second half of the nineteenth century marked the army's increased professionalization, moving it further away from the militia model. The reform of 1868 established universal military conscription as the method for recruiting civilians into a centralized army. ${ }^{9}$ From 1886 onward, the burgher corps were corporately liable for service in the military reserve (Landsturm). ${ }^{10}$ The new Landsturm law of 1907 brought in stricter regulations for the reserve service, and a more rigorous enforcement of the requirement for regular shooting practice. The corps in Waidhofen an der Thaya, for example, encountered some difficulties with this as they had to build a new shooting range for their training. ${ }^{11}$

Before the war, 215 such militias existed in the Austrian half of the monarchy, but they were very unevenly spread geographically. More than half of them were located in Bohemia (132). The crownland with the second highest number of corps (37) was Upper Austria, while other crownlands counted less than 10. There were no corps in Galicia, and only one in Bukovina (in Czernowitz/Cernăuți/Chernitsvi). They comprised a total of fifteen thousand men (two-thirds in Bohemia). ${ }^{12}$ However, this geographical imbalance does not reflect the reality of the militias and shooting guilds in Habsburg Austria. These civic militias should be envisioned in the broader context of civilian armed formations across Cisleithania, as some territories were subject to specific provisions. For example, Tyrol's local defense system, the Standschützen, benefited from a separate legal status from the burgher corps, but show many similarities with them. ${ }^{13}$ The Tyrolean Schützen's specificity had its roots in the organizations of regional territorial defense going back to at least the sixteenth century. But, as Laurence Cole has shown, the decades leading up to the outbreak of World War I saw a massive expansion in the number of shooting ranges and shooters, so that by 1913 around 65,500 men were practicing on a regular basis in Tyrol. ${ }^{14}$ In Galicia, traditional civic guards were organized into shooting associations, such as the "Fowler's brotherhood" (Bractwo Kurkowe) or the Towarzystwo Strzeleckie, and shared many characteristics (deep historical

\footnotetext{
${ }^{9}$ On this development, see Cole, Military Culture, 110-14.

${ }^{10}$ Gesetz vom 6. Juni 1886 betreffend den Landsturm für die im Reichsrathe vertretenen Königreiche und Länder, mit Ausnahme von Tirol und Vorarlberg, Reichsgesetzblatt für die im Reichsrathe vertretenen Königreiche und Länder, XXXI (1886), 297.

${ }^{11}$ Karl Heitzler, Das uniformierte bewaffnete Bürgerkorps der landesfürstl. Stadt Waihofen an der Thaya: Festschrift zum ersten Verbandsschießen der niederösterreichischen Bürger- und Schützenkorps in Waidhofen an der Thaya am 6. August 1911 (Vienna, 1911), 84.

${ }^{12}$ The numbers presented here are from the register of the Home Defense Ministry but are not necessarily consistent or reliable. See the lists by crownland in Österreichisches Staatsarchiv (Austrian State Archives, hereafter ÖStA), Kriegsarchiv (KA), Zentralstellen (ZSt), and Ministerium für Landesverteidigung (MfLV), Sonderreihe, Politischer Teil, K308. The federation of burgher corps reported 194 corps in total (of which 100 belonged to the federation) in 1911, See Neue Freie Presse, 1 July 1911, 9.

${ }^{13}$ Gesetz vom 14. Mai 1874 wirksam für die gefürstete Grafstadt Tirol und das Land Vorarlberg betreffend die Schiessstands-Ordnung, Landesgesetzblatt Tirol und Vorarlberg, VII (1874), 142. See also Otto Stolz, Wehrverfassung und Schützenwesen in Tirol von den Anfängen bis 1918 (Innsbruck, 1960), 171, 183-89.

${ }^{14}$ See Laurence Cole, "Für Gott, Kaiser, und Vaterland": Nationale Identität der deutschsprachigen Bevölkerung Tirols, 1860-1914 (Frankfurt, 2000), 432-36.
} 
legacy, uniforms, shooting) with the burgher corps without enjoying the same legal status. In Lemberg/Lwów/L'viv, a local Bürgercorps had existed up to 1848, and the Towarzystwo Strzeleckie had been its successor, taking over its shooting range and its role in local celebrations, while also reviving older traditions. ${ }^{15}$ The situation was similar in Dalmatia, where a decree from the Defense Ministry in 1914 enjoined the Dalmatian governor to create burgher corps in the region of Ragusa/Dubrovnik by conferring this status on existing shooting associations, which would thus acquire privileges, such as authorization to parade in arms. ${ }^{16}$ Indeed, all over Habsburg Austria several shooting associations sometimes acted as burgher corps without having requested the formal status. The Bokejlska mornarica (Boka Navy) in Cattaro/Kotor (Dalmatia), for example, traditionally paraded in arms at Catholic festivals without any official status. The local authorities tolerated the practice because of its "purely patriotic" character marked by "love of the homeland and devotion to the supreme ruler." In 1899, the mornarica petitioned the emperor for conferment of the official imperial title of "privileged" and the gift of a new flag. ${ }^{17}$ In Galicia, the municipalities of Pilzno and Brzostek similarly asked to upgrade their existing "town guards" to the status of a corps in accordance with the 1851 patent. ${ }^{18}$ Shooting associations from Upper Austria to Silesia also made regular efforts to acquire the status of uniformed corps in the last years before the war. ${ }^{19}$ The number of officially registered militias, therefore, provides at best only an estimate of the armed corporations active in Cisleithania.

By the turn of the century, the burgher corps status inherently implied an active effort to foster Austrian state patriotism. As per the 1851 imperial decree, these civic militias had become corporations whose existence was specially sanctioned by the emperor and were allowed to use state symbols, such as the imperial eagle, on their flags and decorations. Through their presence at patriotic celebrations, the local militias became bearers of imperial loyalty. ${ }^{20}$ This patriotic dimension was given particular emphasis when a statewide union of burgher corps was formed in 1910. The initiative to create an umbrella structure had come not from above but from several of the corps, whose delegations had met in Prague three years earlier. ${ }^{21}$ One of the union's main goals, according to the approved statutes, was "to foster and exercise a dynastic-patriotic feeling among its members and to disseminate it among the population." ${ }^{22}$ Individual corps also underlined this aspect. The 1879 statutes of the corps in Brandýs nad Labem/Brandeis an der Elbe, for example, proclaimed the corps' main goal to be "to ensure and cultivate affection and love for the hereditary ruling dynasty, and to arouse and cultivate a patriotic attitude, civic spirit and concern for the patriotic defense of the country." 23 Many of the statutes reformed after 1907 used the same language

\footnotetext{
${ }^{15}$ See the history of the shooting range described in Kurjer Lwowski, 8 June 1905, 2.

${ }^{16}$ Copy of a decree from the Defense Ministry to the governor in Zara/Zadar, 18 June 1914, ÖStA, Allgemeines Verwaltungsarchiv (AVA), Ministerium des Innern (MdI), Präsidium, K1654, no. 7941/14.

${ }^{17}$ Report from the governor's office in Dalmatia, 7 Nov. 1899, ÖStA, AVA, MdI, Allgemeine Reihe, K2199, no. 37989.

${ }^{18}$ ÖStA, AVA, MdI, AR, K2199, no. 16452/13, 29 Apr. 1913. The file refers to similar demands from Nisko and other towns.

${ }^{19}$ For examples see: ÖStA, AVA, MdI, AR, K2199: in Kuchl, no. 4716/12, 6 Feb. 1912; in Hofkirchen, no. 38141/10, 30 Oct. 1910; in Teschen, no. 34539/10, 5 Sept. 1910. See also the correspondence from the Ministry of Defense explaining the request's dismissal in the case of Krems with reference to previous cases, no. 8200/13, 5 Mar. 1913. Another example in Kratzau/Chrastava (Bohemia) can be found in NA, MV/R, ka 1756, no. 38389/12, 9 Oct. 1912.

${ }^{20}$ On loyalty, see Laurence Cole and Daniel L. Unowsky, eds., The Limits of Loyalty: Imperial Symbolism, Popular Allegiances, and State Patriotism in the Late Habsburg Monarchy (New York, 2007).

${ }^{21}$ Prager Tagblatt, 10 May 1907, 5.

${ }^{22}$ From the statutes of the federation, ÖStA, AVA, MdI, AR, K2199, 23341/09, 10 May 1909.

${ }^{23}$ ÖStA, KA, ZSt, MfLV, Sonderreihe, Politischer Teil, K282, 12, 5590/881, 4 Apr. 1881.
} 
and described the corps' goal as being to "foster in general and at all times love and loyalty to the Emperor and the fatherland, respectability, public spirit, and, in particular, an appreciation of the legal order and peaceful communal life." ${ }^{24}$ In this respect, the civic militias fulfilled locally very similar roles to the veterans' associations. ${ }^{25}$

While the militias everywhere saw themselves first and foremost as bulwarks of dynastic loyalty, their links to the growing nationalist movements differed according to the region. The case of civic militias tends to blur the strict divisions between nationalist associations, on the one hand, and supranational patriotic associations, on the other. The small-town context meant that men could be members of several associations simultaneously. Nationality, of course, does not feature anywhere in the official statutes or in the militias' membership restrictions. Moreover, the numerous Czech-speaking corps in Bohemia attest to the militias not being an exclusively "German" institution. ${ }^{26}$ However, in Northern Bohemia in particular, militias sometimes espoused German nationalism. For example, in 1913 the Schützenkorps in Brüx/Most asked for permission to attend a gymnastics Turnverein competition in Leipzig with their sabers, indicating a potential overlap in the membership of the two associations. ${ }^{27}$ In 1902, the Defense Ministry rejected a first attempt to form a union of German Schützenkorps from Northern Bohemia because "the underlying national separation [was] not outweighed by the strong emphasis on the state" patriotism. ${ }^{28}$ Czech-speaking militias also defended their national credentials. The magazine "Czech Guardsman" explained that "although it has to this day been denied by many enemies of the corps, we have convinced our general public of the national work of the Czech corps." 29 The mix of imperial, national, and local allegiances can be seen in the corps' flags, which sometimes displayed national as well as imperial symbols. The corps in Príbram, for example, was falsely accused in the German nationalist press of having switched the colors of its flag from black and gold (imperial colors) to red and white (Czech colors) when the flag had, in fact, been red and white since 1860 and carried the imperial initials, the Czech lion, a crown, and the town's coat of arms. ${ }^{30}$ In the Czech national context, competition with the more recent Sokol gymnastics movement created tensions. For example, in Třeboň/ Wittingau the "youthful" Sokol was the only town association not to attend the 1894 corps jubilee celebrations. ${ }^{31}$ Yet, even the Sokols had some features in common with the militias:

\footnotetext{
${ }^{24}$ See, among others, the statutes in Czech from Unhošt (1912) and Klatovy (1912), ÖStA, KA, ZSt, MfLV, Sonderreihe, Politischer Teil, K282, 12 XVIII, 671/13, 13 May 1913 and 1244/13, 3 July 1913, respectively; also the statutes in German from Gurkfeld (1909), ÖStA, KA, ZSt, MfLV, Sonderreihe, Politischer Teil, K295, XVIII 461/ 09, 28 May 1909; also Statuten des k.k. priv. bürgerlichen Schützenkorps in Warnsdorf (Varnsdorf, [1911]), 1.

${ }^{25}$ Cole, Military Culture, passim and p. 306 for a similar wording in the case of the Kriegercorps.

${ }^{26}$ The historiography tends to still present them as "German" with Czech-speaking corps as an exception, underestimating their numbers and significance, see Marie Macková, "Spolky ostrostřelců a jejich postavení ve venkovských mestěch druhé poloviny 19. stoleti'" [Sharpshooters' associations and their position in rural towns in the second half of the nineteenth century], in Documenta Pragensia XVIII: od středověkých bratrstev k moderním spolkům [From medieval brotherhoods to modern associations], eds. Václav Ledvinka and Jiří Pešek (Prague, 2000), 221-34.

${ }^{27}$ Národní archiv (Czech National Archives, hereafter NA), Ministerstvo vnitra Rakousko (MV/R), ka 1756, no. 23911/13, 18 June 1913.

${ }^{28} \mathrm{NA}, \mathrm{MV} / \mathrm{R}$, ka 1756, no. 17746/02, 29 Apr. 1902.

${ }^{29}$ Česky gardista, 1 Dec. 1905, 1.

${ }^{30}$ Report from the Bohemian Governor's Office: NA, MV/R, ka 1756, no. 40429/05, 1 Sept. 1905.

${ }^{31}$ Státní okresní archiv Jindřichův Hradec (SOkA, State District Archives Jindřichův Hradec) Sbor ostrostř̌elců Třeboň, Památní kniha c. k. priv. měštanských ostrostř̌lců.
} 
they sometimes marched during patriotic celebrations in full uniform, and, above all, they integrated shooting in their activities; from the 1890s onward several Sokols had shooting sections and on their own initiative organized training in army shooting ranges from 1912 to $1914 .^{32}$ Patriotic associations could have national traits, and national associations could pursue patriotic goals, which should not be a surprise in a world where empire and nation were not binary opposites, as Pieter Judson has recently argued. ${ }^{33}$

The growth of Polish shooting associations in Galicia before the war also illustrates the complex intermingling of imperial and national goals. Several paramilitary organizations were created after 1908: the Zwiazek Strzelecki, the Strzelec, the Polskie Drużyny Strzeleckie, the Drużyny Podhalanskie, and the peasant squads of the Drużyny Bartoszowe. ${ }^{34}$ (The Ukrainians created the Sičovi Strilci in the same period.) Estimates of the numbers of members range from 8,500 to 11,000 by the outbreak of war. $^{35}$ The rise of Polish paramilitary units is often presented as part of Polish nation-building efforts against the Russian Empire and Ukrainian nationalism at home. ${ }^{36}$ However, the strong emphasis on Polish nationalism in these formations and their role in the subsequent war should not obscure the fact that before 1914 they were also part of an Austrian policy across the empire to prepare civilians more effectively in the use of weapons, and were therefore integrated to an extent into an Austrian patriotic project. The Austrian government encouraged the formation of civic guards in Galician towns to defend public order and the border regions, and suggested giving them the same legal status as the burgher corps, although "the particular conditions in Galicia would call for the creation of a specific status for these corporations." 37 In discussions about preparing Galicia for war through the creation of military formations, the old pre-1848 Bürgercorps in Lemberg/Lwów/L'viv was sometimes still put forward as a model. ${ }^{38}$ The debates about Polish units were part of a wider effort to (re)activate civic militias in the last decade before the war.

Heightened international tensions in the immediate prewar years provide the first explanation for the growth of civic militias and other shooting formations. In the years leading up to World War I, the Ministry of Defense introduced measures to encourage the practice of shooting among the population. Civic militias became one of the institutions that were supposed to participate in promoting shooting as a skill. State support included financial assistance in building shooting ranges, access to garrison shooting training grounds,

\footnotetext{
${ }^{32}$ Marek Waic, Tělovýchova a sport ve službách české národní emancipace [Physical education and sport at the service of Czech national emancipation] (Prague, 2014). For the shooting sections, see for example: Týn nad Vltavou (1892), Mšeno (1894). On the paramilitary aspects of the Sokols, see Claire Nolte, The Sokol in the Czech Lands to 1914: Training for the Nation (Basingstoke, 2002), 94-95.

${ }^{33}$ Pieter M. Judson, The Habsburg Empire (Cambridge, 2016).

${ }^{34}$ Kai Struve, Bauern und Nation in Galizien: über Zugehörigkeit und soziale Emanzipation im 19. Jahrhundert (Göttingen, 2005), 289; on the relationship between the different paramilitary formations see Waldemar Potkański, "Próby współdziałania formacji zbrojnich tworzączych polską irredentę przed 1914 r." [Attempts at cooperation of Polish irredentist armed formations before 1914], Dzieje Najnowsze 35, no. 1 (2003): 31-34.

${ }^{35}$ Klaus Bachmann, Ein Herd der Feindschaft gegen Russland: Galizien als Krisenherd in den Beziehungen der Donaumonarchie mit Russland (1907-14) (Vienna, 2001), 92.

${ }^{36}$ See Bachmann's analysis and Patrice Dabrowski, Commemorations and the Shaping of Modern Poland (Bloomington, 2004), 187-89. On the attitude of the Austrian government, see Waldemar Potkański, "Władze austriackie wobec polskiego ruchu militarnego przed 1914 rokiem w Galicji" [The Austrian government and the Polish military movement before 1914 in Galicia], Bezpieczeństwo: teoria i praktyka 1 (2011): 81-92.

${ }^{37}$ ÖStA, AVA, MdI, AR, K2199, no. 16462, 29 Apr. 1913.

38“Sen o gwardji," Kurjer Lwowski, 19 Dec. 1912, 6.
} 
the lending of weapons, and the supply of munitions. ${ }^{39}$ Civic militias and shooting clubs were also lent or allowed to purchase older army rifles with which to train. ${ }^{40}$ After 1908, initiatives to train the youth and form youth guards (Jugendwehren) for boys aged between fourteen and twenty in every district provided the militias with another opportunity to take part in military preparations for a future conflict. The success of this measure can be gauged from the number of shooting clubs, which went from 260 in 1912 to 429 in 1913, and the number of secondary school students taking part in shooting practice in the youth guards, fifteen thousand in 1913. ${ }^{41}$ The militias' involvement in youth training was even more clearly formalized in April 1914, when all the burgher corps had to create schools of young sharpshooters (Jungschützenschulen) to teach adolescents how to manipulate a weapon. ${ }^{42}$ The generic statutes of the youth guards included the requirement that young people be prepared for the military with "military exercises, instruction in the manipulation of weapons and in shooting with army weapons." The goal was to form "state citizens strong in body, spiritually and morally healthy, enlightened, practical, and loyal." 43 Knowing how to shoot was hence deemed an essential component not only of military preparation but also of good citizenship. Regular practice was perceived as a patriotic duty.

By focusing only on their military significance, it would be easy to simply view these militias as remnants from another era that found a limited new function around 1910 in actively promoting shooting among the population. Their trajectory would then appear to be a transformation from local military units to army auxiliary forces playing a minor role in the general militarization of Habsburg society prior to World War I. ${ }^{44}$ As the Ministry of Defense commented concerning the creation of a statewide union in 1909, "in those days [1851], the spine of the Bürger- und Schützenkorps was still the municipality, today it is the state. In those days, they had more or less the character of a town troop, a civic militia (Bürgermiliz), today they are corporations liable for reserve service, whose full availability for all reserve duties without distinction of type or location is legally ensured." 45 However, this practical conception linked to military efficiency reflected the army's own concerns. It did not necessarily correspond to the militias' self-perception, and it misses a large part of their relevance at the local level: their social function.

Regular shooting practice was not only about being a good Habsburg citizen preparing for the next war, it was also about being a bourgeois man. In that sense, it stood in continuity with the practices of civic militias since early modern times. Their relevance as fighting units, even in earlier periods, has long been questioned. However, early modern historians have recently shown that their poor military record should not detract from the real significance of their roles in policing and as a political and civic force. ${ }^{46}$ It seems the military angle is not

\footnotetext{
39“"Bestimmungen über die Unterstützung des freiwilligen Schiesswesens”, ÖStA, AVA, MdI, AR, K2199, no. 17268/ 09, 17 May 1909.

${ }^{40}$ Examples: Oberösterreichisches Landesarchiv (Upper Austrian Regional Archives, Linz), Archiv der k. k. Statthalterei, Allgemeine Reihe, K2680, no. 15295, 5 July 1905 and K2915, no. 12141, 10 May 1907.

${ }^{41}$ Günther Kronenbitter, "Krieg im Frieden": Die Führung der k.u.k. Armee und die Grossmachtpolitik ÖsterreichUngarns 1906-1914 (Munich, 2003), 226.

${ }^{42}$ ÖStA, AVA, MdI, AR, K2199, no. 28030, 19 May 1914.

${ }^{43}$ ÖStA, AVA, Ministerium für öffentliche Arbeiten, Fz 1302, 510 XXII, 16 Sept. 1909.

${ }^{44}$ On militarization in the lead-up to the war see Cole, Military Culture, chapter seven.

${ }^{45}$ Report from the Ministry of Defense, ÖStA, AVA, MdI, AR, K2199, no. 23341/09, 10 May 1909.

${ }^{46}$ See Maarten Prak, "Citizens, Soldiers, and Civic Militias in Late Medieval and Early Modern Europe," Past \& Present 228 (Aug. 2015): 93-123 and B. Ann Tlusty, The Martial Ethic in Early Modern Germany: Civic Duty and the Right of Arms (Basingstoke, 2011).
} 
the only appropriate lens through which to examine civic militias. At the turn of the twentieth century, in a context of growing democratization, bourgeois men connected preparation for combat against an external enemy to the struggles against internal enemies. Shooting was promoted not only as a means to defend the homeland but also to protect the social order and defend private property, as explained in a pamphlet from 1894:

In our current times, another enemy of the hard-working, peaceful bourgeoisie lurks in waiting for the potential wartime confusion of political circumstances: international socialism and anarchism, reaching their hands towards the property of the industrious bourgeois .... When state forces will need to direct their weapons against an external enemy, must we not make ourselves ready to stop attack from the inner enemy and to quell the attempts at upheaval with an armed hand? The propertied bourgeoisie has every reason not to fold their arms, but instead to train themselves in time to handle weapons. The shooting clubs, as offshoots of the civic militias, should also keep in view this potential self-defense. ${ }^{47}$

This plea for self-defense signals the bourgeois ethos of civic militias, which will be explored in the next section.

\section{Bourgeois Belonging}

The civic militias were exclusive institutions whose members represented the town's bourgeois classes. The privileges of bearing arms and wearing a uniform (which the men often had to purchase themselves) were limited to a small group of local men, and hence became a potent sign of bourgeois respectability. In many towns, admission into the burgher corps was explicitly granted only to the town's citizens (Bürger). The statutes of the Schützenkorps in Falkenau/Sokolov (Bohemia), for example, mention that members should be "respectable" Bürger (or their sons) or "respectable" tradesmen domiciled in Falkenau, provided that citizens always formed two-thirds of the corps. ${ }^{48}$ In Volkabrück, only landowners, house owners, or independent tradespeople, and their sons could become members of the militia. ${ }^{49}$ In Domažlice/Taus, aside from local citizens, civil servants and artists could also gain entry, but the members all had to be "respectable, independent, wealthy, and physically fit to serve." ${ }^{50}$ In practice, the corps' assembly often decided on membership, and they probably had local knowledge of who belonged to the local bourgeoisie. As historian Ewald Hiebl has pointed out in the case of Hallein, the local civic guard was an institution endowed with bourgeois prestige, which united different strata of the middle classes. Craftsmen and tradespeople, the heart of the traditional bourgeoisie, dominated in the corps, rather than employees and teachers, who dominated in national associations. ${ }^{51}$ Honorific titles in the corps were given to local noblemen or industrialists, while the rank and file of the corps was composed of lower-middle-class men. The militia's role in upholding bourgeois values was sometimes made explicit, as in Sankt Veit (Carinthia) where the statutes list the "cultivation

\footnotetext{
${ }^{47}$ Anton Baran, Aufgaben der Schützenvereine (Vienna, c. 1894), 22-23.

${ }^{48}$ Statuten für das $k$. $k$. priv. bürgerliche Schützen-korps in Falkenau (Falkenau, [1900]), 7.

${ }^{49}$ Alexander von Reden, Oberösterreichs heimliche Regimenter: die Bürger- und Schützenkorps von der Gründung bis zur Gegenwart (Salzburg, 1987), 244.

${ }^{50}$ Stanovy měšt'anského spolku střeleckého v Domažlicích (Domažlice, 1902), 6.

${ }^{51}$ Ewald Hiebl, "The Instrumentalization of Bürgerlichkeit: Associations and the Middle Class in Hallein, Austria from the Nineteenth Century to the Beginning of the Twentieth Century," in Civil Society, Associations and Urban Places: Class, Nation and Culture in Nineteenth Century Europe, eds. Graham Morton, Boudien de Vries, and R. J. Morris (Aldershot, 2006), 55-76.
} 
of bourgeois decorum (Wohlständigkeit)" among the corps' goals. ${ }^{52}$ Membership in the militia was an integral part of bourgeois class identity, as opposed to the aristocracy and the rising working classes. $^{53}$

The bourgeois nature of the militias reflected both a class ethos and a local conception of citizenship. Membership in the urban citizenry was often restricted in Habsburg Austria until 1918, even after universal suffrage was introduced for parliamentary elections in 1907. Citizenship at the municipal level was considered a matter of property administration and centered on private ownership. To be able to vote, one either had to pay a certain level of tax or be considered a member of the "intelligentsia" (priests, civil servants, university graduates). The proportion of voters among the town's population varied widely across Cisleithania according to the region and the size of the municipality. In some cases, women, as holders of property, were allowed to vote albeit by proxy. Everywhere, however, local suffrage remained unequal as the votes of the wealthiest citizens were given more weight through a system of separate voting bodies. ${ }^{54}$ The franchise was also especially restricted in larger provincial cities and business centers, which were more likely to have a historical burgher corps.

This nonegalitarian conception of citizenship considered property as the basis of belonging and was anchored in the locality, as if the houses and walls were represented. The town dwellers voting had to have a "material or spiritual community of interest with the municipality." 55 This nineteenth-century local citizenship based on exclusivity shows the legacy of early modern forms of municipal governance. It is worth remembering that urban citizenship had been the norm in Europe for centuries, and that participation in local militias and watch duties were an important part of its requirements. ${ }^{56}$ Although the modern revolutions recast the link between the arming of men and citizenship, this did not mean a general acceptance of the French revolutionary model of the conscript "citizen in arms." 57 The Austrian army elite remained opposed to this model and to universal suffrage despite the use of conscription up until World War I. ${ }^{58}$ And even in France, the institution of the National Guard revealed all the ambivalence of the "new" citizen-soldier model, which had by no means eliminated the social exclusivity principle of earlier militias. Its inception saw bourgeois citizens defending

\footnotetext{
${ }^{52}$ ÖStA, KA, ZSt, MfLV, Sonderreihe, Politischer Teil, K295, no. XVIII 659, accepted on 15 Nov. 1911.

${ }^{53}$ For more details on the bourgeoisie in the different regions of the Habsburg monarchy in the nineteenth century, see the several-volume collection that explores its evolutions, demographic makeup, culture, relationship to modernity, and other themes: Bürgertum in der Habsburgermonarchie, 6 vols. (Vienna, 1990-2000).

${ }^{54}$ Peter Urbanitsch, "Die Gemeindevertretungen in Cisleithanien," in Die Habsburgermonarchie 1848-1918, vol. 7/ 2: Verfassung und Parlamentarismus: Die regionalen Repräsentativkörperschaften, eds. Helmut Rumpler and Peter Urbanitsch (Vienna, 2000), 2199-2281; Birgitta Bader-Zaar, "Rethinking Women's Suffrage in the Nineteenth Century: Local Government and Entanglements of Property and Gender in the Austrian Half of the Habsburg Monarchy, Sweden, and the United Kingdom," in Constitutionalism, Legitimacy, and Power: Nineteenth-Century Experiences, eds. Kelly L. Grotke and Markus J. Prutsch (Oxford, 2014), 107-26; Jeremy King, "The Municipal and the National in the Bohemian Lands, 1848-1914," in Nationalism and the Reshaping of Urban Communities in Europe, 1848-1914, eds. William Whyte and Oliver Zimmer (Basingstoke, 2011), 23-24.

${ }^{55}$ Urbanitsch, "Die Gemeindevertretungen in Cisleithanien," 2203.

${ }^{56}$ See Maarten Prak, Citizens without Nations: Urban Citizenship in Europe and the World, c. 1000-1789 (Cambridge, 2018).

${ }^{57}$ Jörn Leonhard and Ulrike von Hirshhausen, "Does the Empire Strike Back? The Model of the Nation in Arms as a Challenge for Multi-Ethnic Empires in the Nineteenth and Early Twentieth Century," The Journal of European Modern History 5, no. 2 (2007): 194-221.

${ }^{58}$ Christa Hämmerle, "Back to the Monarchy's Glorified Past? Military Discourses on Male Citizenship and Universal Conscription in the Austrian Empire, 1868-1914," in Representing Masculinity: Male Citizenship in Modern Western Culture, eds. Stefan Dudink, Karen Hagemann, and Anna Clark (London, 2007), 151-68.
} 
property against disorder; in the following decades, it supposedly represented the people in arms but relied on bourgeois recruitment, thereby highlighting the tensions inherent in liberalism. ${ }^{59}$ The national guards created in towns all across imperial Austria in 1848 also reflected this ambivalence: they claimed to embody "the people," but in practice only propertied men were considered trustworthy enough to be armed citizens. ${ }^{60}$ In 1848, the burgher corps, as preexisting institutions, in some towns merged with the local national guards, and in others tried to maintain their separateness. ${ }^{61}$ Whether the different units merged or not, their duties included similar tasks, such as patrolling and maintaining order during revolutionary upheaval. In Steyr, for example, the burgher corps ran into tensions with the National Guard as they sought to attract new recruits, and its members positioned themselves as the original citizens in arms defending the public good. ${ }^{62}$ Local municipal contexts varied, but the 1848 "arming of the people" reveals the blurred boundary between urban forms of armed militias and the revolutionary national guards. ${ }^{63}$

By the end of the nineteenth century, this exclusive conception of citizenship was put into sharper relief by the rise of the working classes and demands for greater political participation. Most towns experienced a widening of the electorate on the municipal level as new classes pushed for their inclusion, and the bourgeoisie often tried to hold on to its power. Austrian liberalism continued to use the rhetoric of universal citizenship while increasingly upholding the social status quo. The reconfiguration of Austrian politics intensified the union of different factions against the inclusion of the lower classes into the political process. As the boundaries of inclusion in the local citizenry/bourgeoisie kept being redefined, the forces dominating local municipal politics were committed to the defense of property and to upholding social hierarchies. ${ }^{64}$ The burgher corps, embodying the bourgeoisie in arms, symbolized protection of the Bürger against workers at a time when a growing political participation could strengthen the Social Democrats. Debates about the enlargement of the franchise also had a spatial resonance, as both the public space and the public sphere were threatened with invasion by the lower classes. ${ }^{65}$

\footnotetext{
${ }^{59}$ On 1789, see Micah Alpaugh, "A Self-Defining 'Bourgeoisie' in the Early French Revolution: The Milice Bourgeoise, the Bastille Days of 1789, and Their Aftermath,” Journal of Social History 47 no. 3 (2014): 696-720; on the National Guard during the July Monarchy, see Mathilde Larrère, L'urne et le fusil: la garde nationale parisienne de 1830 à 1848 (Paris, 2016).

${ }^{60}$ Judson, The Habsburg Empire, 177-79. On the national guards, see also Jaroslav Kř́žzek, Národní gardy v roce 1848: K otázce první ozbrojené moci buržoasie v Čechách [National guards in 1848: On the question of the first armed forces of the bourgeoisie in Bohemia] (Prague, 1954).

${ }^{61} \mathrm{~A}$ common command, for example in Brno: Gottfried Zelniczek, Geschichtliche Notizen über das k.k. priv. bewaffnete Bürger- und Schützen-Corps der königl. Landeshauptstadt Brünn (Brno, 1898), 102. in Kouřim, the corps almost disappeared with the competition of the National Guard: M. J. Beneš, Déjiny c.k. priv. sboru měštanských ostrostřelců král. města Kouřimi: pamětní spis k slavnosti 350tého trvání téhož sboru [History of the imperial royal privileged corps of civic sharpshooters of the royal town of Kouřim] (Kourim, 1900), 6; in Grottau, the fusion created great frictions, Josef Schubert, Geschichte der k. k. priv. Schützen-Gesellschaft in Grottau (Hrádek nad Nisou, 1889), 157.

${ }^{62}$ Chronik des k.k. priv. uniformierten bewaffneten Bürger-Corps der l. f. Stadt Steyr in Oberösterreich (Steyr, 1898), 55-59.

${ }^{63}$ For a similar argument on the continuity between urban militias in the Netherlands, see Carolien Boender, “'Old Citizenry' in a New State: Civic Militias and Political Crises in Haarlem and Groningen in the First Half of the Nineteenth Century," Low Countries Historical Review 133, no. 3 (2018): 44-45.

${ }^{64}$ Pieter Judson, "Rethinking the Liberal Legacy," in Rethinking Vienna 1900, ed. Steven Beller (New York, 2001 ), 72.

${ }^{65}$ Maureen Healy demonstrates how the trope of Vienna "under siege" was interpreted in this way in 1883 , see Maureen Healy, “1883 Vienna in the Turkish Mirror,” Austrian History Yearbook 40 (2009): 101-13.
} 
The deployment of civic militias during workers' demonstrations emphasized the connection between the two dimensions: threats to public order were also experienced as threats to the social order. In Steyr, for example, the burgher corps was called upon by the mayor during workers' unrest in 1889. ${ }^{66}$ In Trautenau/Trutnov, in preparation for the first May Day celebrations in 1890, militia men patrolled the town, ready to intervene to curb workers' "excesses" as the day "had been for a while described as very critical." ${ }^{\text {" T }}$ The first May Day celebrations in the early 1890s had indeed "aroused considerable alarm among the ruling classes" and in Vienna the authorities had taken special precautions to avoid riots. ${ }^{68}$ The burgher corps' statutes required them to help maintain "peace and order" (Ruhe und Ordnung; klid a poŕádek) when instructed by the local authorities (district officers), and this notion of peace and order was central to the militias' self-perception. ${ }^{69}$ The turn of the century further cemented the link between public order, the absence of trouble in city streets (Ruhe), and preservation of the social order, the way society was organized. ${ }^{70}$ The $^{2}$ mobilization for universal suffrage in 1905, which saw hundreds of thousands of workers march in Austrian cities, further heightened bourgeois fears that the traditional structures of power might be undermined. ${ }^{71}$ The power and efficiency of this mass mobilization was threatening for a whole section of Austrian society, whether or not they supported the suffrage reform. What frightened them were the mass demonstrations, the accompanying violence, and the spread of strike movements, as well as the potential for general unrest that they revealed. The Landsturm reform of 1907 raised debates about the use of militias to provide "military assistance" in case of unrest. The military newspaper, Danzers-Armee Zeitung, welcomed the measure, "which should provoke the anger of state enemy elements and the real joy of every patriot." The measure would also clear militias of "elements of doubtful attitude" and provide them with a base "which [was] not fruitful terrain for SocialDemocrats and other state enemy rabble." ${ }^{72}$ From the 1890s onward, fears of the internal enemy-workers and Social Democrats-echoed fears of the external enemy. The speech given by the corps leader in Sankt Joachimthal/Jáchymov (Bohemia) for the militia's jubilee in 1910 outlined the mission of bourgeois armed citizens: "If it had to come, by God's will, that an enemy, wherever he might be from, the interior or the exterior, would disturb the peace and quiet of the country, attack the rights and honor of our Emperor, the Schützenkorps would not waste an instant in responding to this call, weapons in hand."73

The debate around the creation of the Vienna civic militia in 1905 offers an example of bourgeois fears and the promotion of civilian armed defense. Interestingly, Vienna had not

\footnotetext{
${ }^{66}$ Chronik des k.k. priv. uniformierten bewaffneten Bürger-Corps der l. f. Stadt Steyr, 213.

${ }^{67}$ Jahres-Bericht des $k$. $k$. priv. Scharfschützencorps G. d. C. Freiherr von Gablenz in Trautenau (Trutnov, 1893) 18-19.

${ }^{68}$ Chris Wrigley, "Red May Days: Hopes and Fears in Europe in the 1890s," in Crowd Actions in Britain and France from the Middle Ages to the Modern World, ed. Michael T. Davis (Basingstoke, 2015), 208-22. On May Day in Austria, see Harald Troch, Rebellensonntag: der 1. Mai zwischen Politik, Arbeiterkultur und Volksfest in Österreich (1890-1918) (Vienna, 1991).

${ }^{69}$ Metternich theorized that peace and order are "inseparable notions, such as cause and effect" see Clemens von Metternich, "Brief an den österreichischen Aussenminister Graf Buol-Schauenstein (1852)," in Wolfgang Frühwald, "Ruhe und Ordnung": Literatursprache, Sprache der politischen Werbung. Texte Materialen, Kommentare (Munich, 1976), 35.

${ }^{70}$ See Thomas Lindenberger, "Ruhe und Ordnung," in Deutsche Erinnerungsorte II, eds. Etienne François and Hagen Schulze (Munich, 2001), 469-84.

${ }^{71}$ On workers' demonstrations in Habsburg Austria in 1905, see Jakub S. Beneš, Workers and Nationalism: Czech and German Social Democracy in Habsburg Austria, 1890-1918 (Oxford, 2017).

${ }^{72}$ Danzers Armee-Zeitung, 5 Dec. 1907, 6.

${ }^{73}$ Státní okresní archiv Karlovy Vary, Ostrostřelci Jáchymov, Kronika ostrostřelců (in German).
} 
had a burgher corps comparable to those of the provincial cities since the dissolution of the National Guard after 1848. The only institution of this kind was the DeutschmeisterSchützenkorps, created in 1897, which included both veterans of the Deutschmeister regiment and Viennese Bürger. ${ }^{74}$ The creation of the Wiener Bürger-Scharfschützenkorps in 1905 was framed as a self-defense tool for the bourgeoisie. The militia participated in Christian Social mayor Karl Lueger's broader strategy in upholding the social order. ${ }^{75} \mathrm{He}$ envisioned the corps as an active force, and invited the younger sons of citizens to participate: "They should not entertain themselves, but instead, in the most decisive moment when the standard forces abandon the population, make order independently . . . . It is very necessary, as the revolutionary current runs ever more rampant." ${ }^{76}$ In the context of violent gangs (Platten) threatening public safety in Vienna, the civic militia was also conceived as a means for the bourgeoisie to defend private property. ${ }^{77}$ Fears around private safety generated by the raids of these gangs were widespread at the time, especially among pub owners. A memorandum sent from a union representing more than eight hundred innkeepers detailed the violent acts of the youth gangs destroying pub property and attacking owners and guests with knives, and the insufficient intervention by an overwhelmed police force. They condemned the sentencing of an innkeeper who had fired a revolver to defend himself and called attention to the lack of protection they suffered from. ${ }^{78}$ A year later, a newspaper article reported that the leadership of the Scharf-Schützenkorps intended to intervene against attacks by the Platten for the safety of passers-by and shops. ${ }^{79}$ In 1907, the Social Democrat Party newspaper, Arbeiter Zeitung, mocked the several-hundred-men-strong unit, doubting their fighting spirit in view of the bellies of these "landlords." ${ }^{\prime 0}$ Lueger thus (re)created a traditional institution to defend Christian Social ideals around the rights of property owners and respect for public order. The heightened social conflicts and demonstrations of the years 1905-7 had raised fears among their opponents, which gave new meaning to old institutions like the burgher corps. ${ }^{81}$

On the flip side of this anxious discourse, other classes called into question bourgeois men's ability to defend themselves and the reliability of militias as a fighting force. The bourgeois ethos of the burgher corps could also be gently mocked for its lack of martial spirit. The Czech burgher corps' newspaper reflects these insecurities over the militia's function in upholding bourgeois order, while being mocked for their uselessness. ${ }^{82}$ An article on the Prague burgher corps commented that they "mostly ha[d] as their ultimate object the 'storming' of a brewery or another place of entertainment; the well-meaning will not hold against them the brave 'bourgeois' nature of this [behavior]." ${ }^{\prime 3}$ Reporting on municipal council debates on the subsidy paid to the burgher corps, the local Social Democrat newspaper in Graz made fun of

\footnotetext{
${ }^{74}$ Satzungen für das Deutschmeister-Schützen-korps (Vienna, [1911]), 7-8.

${ }^{75}$ Lueger, for example, nominated men as new Bürger who conformed to traditional social values and dubbed them the "grenadiers of social order," see John Boyer, Culture and Political Crisis in Vienna: Christian Socialism in Power, 1897-1918 (Chicago, 1995), 10.

${ }^{76}$ Illustrierte Kronen Zeitung, 21 Apr. 1905, 6.

${ }^{77}$ On the "Platten" see Wolfgang Maderthaner, Unruly Masses: The Other Side of Fin-de-Siècle Vienna (Oxford, 2008).

${ }^{78}$ ÖStA, AVA, MdI, AR, K2200, no. 42204, 14 Sept. 1905.

${ }^{79}$ Illustrierte Kronen Zeitung, 25 Nov. 1906, 26.

${ }^{80}$ Arbeiter Zeitung, 11 Apr. 1907, 6.

${ }^{81}$ On social fears in Belle Époque Europe, see Matteo Millan, “The Shadows of Social Fear: Emotions, Mentalities and Practices of the Propertied Classes in Italy, Spain and France (1900-1914)," Journal of Social History 50, no. 2 (2016): 336-61.

${ }^{82}$ Český gardista, 1 Feb. 1906, 1.

${ }^{83}$ (Neuigkeits) Welt-Blatt, 16 Apr. 1907, 3.
} 
the formation's uselessness: "If the enemy really should come face to face with our Bürgercorps, they would at most run the risk of dying of laughter." ${ }^{\prime 4}$ Popular representations of small-town militias also reflected perceptions of the corps as more concerned with meaningless bourgeois decorum, beautiful uniforms, and beer glasses. ${ }^{85}$

Yet, the militias' predominantly social character meant they played an important role in urban communities in the nineteenth century. Emphasis on the support of other members, civic pride in local identity, and the defense of property and social hierarchies constituted means to engage with the processes of modernization. The end of the nineteenth century saw the publication of several historical accounts of the local corps, which documented their past deeds. ${ }^{86}$ The writers often attempted to trace the corps' origins as far back as possible and presented them as part of a (partially invented) tradition of local prestige and honor. Even without archival records, the corps in Braunau/Broumov could claim to be "one of the oldest in Bohemia" that had consistently been characterized by its "civic spirit" (Bürgersinn). The continuity with a glorious past was here used as a tool to navigate the present, a reassuring confirmation of the endurance of the corps' values: "the historic past lives on in [the Schützenkorps], and as long as the Braunau Schützenkorps in our materialistic times does not lose its direction towards its ideal goals, it will continue to exist and to prosper." ${ }^{\prime 7}$ The militias were part of the reconfiguration of a sense of place, anchoring new modes of Bürger and local self-understandings. ${ }^{88}$ The painted shooting panels often depicted historical scenes or contained representations of the corps as an urban community. ${ }^{89}$ One of the shooting panels of the burgher corps in Duchcov/Dux, for example, represented the corps under a huge hat and was entitled "civic crown" (Bürgerkrone). ${ }^{90}$

Moreover, the construction or reconstruction of shooting ranges and shooting clubhouses all over Austria at the time attests to the role militias played in bourgeois urban topographies. Shooting as a sport, but also as a community pastime, formed part of the structuring of bourgeois urban identity. The shooting association's park in Cracow is a good illustration of the link between bourgeois urban development initiatives and marksmanship. Built in the 1830s by the local Towarzystwo strzeleckie, it had a shooting pavilion and was a place to practice shooting, but also to take walks, have refreshments, or go for entertainment. In

\footnotetext{
${ }^{84}$ Arbeiterwille, 28 Sept. 1901, 3.

${ }^{85}$ See, for example, a mock dialogue in "Schützenkorps," Die Muskete, 25 June 1908, 2. For a Czech caricature of the Habsburg-era corps in the interwar period, see the film Anton Spelec, ostrostřelec [Anton Spelec, sharpshooter], dir. Martin Frič (1932).

${ }^{86}$ For example: Christian D’Elvert, Zur Geschichte der Schützenvereine und Bürgercorps in Mähren und Oesterr.Schlesien (Brno, 1892); František Herold, Památné události c.k. priv. měštanského sboru ostrostřeleckého $v$ Plzni (Plzeň, 1876); Gottfried Zelniczek, Geschichtliche Notizen über das k.k. priv. bewaffnete Bürger- und Schützen-Corps der königl. Landeshauptstadt Brünn (Brno, 1898).

${ }^{87}$ Emil Schreiber, Geschichte des k.k. priv(ilegierten) bürg(er)-l(ichen) Scharfschützen-Corps zu Braunau in Böhmen (Broumov, 1893), preface, 3.

${ }^{88}$ See Oliver Zimmer, Remaking the Rhythms of Life: German Communities in the Age of the Nation-State (Oxford, 2013).

${ }^{89}$ For a study of the decoration of shooting panels see Jana Mezerová, "Monarchie na mušce aneb modernizační procesy 19. století na střeleckých terčích" [The monarchy as target or the modernization processes of the nineteenth century on shooting panels], Acta Musei Nationalis, 67, nos. 1-2 (2013): 3-10.

${ }^{90} J a n a$ Mezerová, “Ostrostřelecká paráda. Mystifikační akty a instrumentalizace historie, jejich motivace a způsoby uplatnění v činnosti ostrostřeleckých spolků” [The sharpshooters’ parade: Mystifications and instrumentalization of history, their motivation and forms of application in the activity of the shooting associations], in Historické fikce a mystificace $v$ české kultuře 19. století [Historical fiction and mystification in the Czech culture of the nineteenth century], eds. Martin Hrdina and Kateřina Piorecká (Prague, 2014), 238-46.
} 
short, it became an urban park for socialization, similar to those that sprang up in the rest of Europe in the nineteenth century. ${ }^{91}$ The shooting association in Tarnów built a similar park a few decades later. The strelecký ostrov (archers' or shooters' island) park in the middle of Prague had expanded its functions since the Middle Ages and was widely used for strolling or for other types of gatherings, but it also remained the local burgher corps' shooting ground until 1913. Formally owned by the Prague municipality, the corps nonetheless enjoyed privileged access to it for shooting practice. ${ }^{92}$ The shooters' island in České Budějovice/Budweis, created at the end of the nineteenth century by the local corps, also comprised a shooting range and a beer garden. In smaller towns, such as Mährisch Schönberg/Šumperk, the shooters' clubhouse was often the center of cultural and social life. ${ }^{93}$ They hosted balls, political meetings, entertainment, and often a restaurant. The grandeur of some of the shooting clubhouses built at the turn of the century (in Tetschen/Děćín in 1904, e.g., or in Jägerndorf/Krnov in 1908) demonstrates their relative importance among the town's public buildings. The burgher corps in Carlsbad built the gigantic neo-gothic Grand Hotel Schützenhaus in 1901, which housed a theater, a hotel, a ballroom, and the clubhouse. ${ }^{94}$ The militias' presence in the spaces of cities and towns was not limited to a specific building or park; it was also in evidence during their regular uniformed and armed parades through the streets for special occasions.

\section{Embodying the Social Order}

Newspaper mentions of the civic militias in this period frequently refer to their participation in patriotic or church celebrations. The first duty listed in many burgher corps' statutes was to "enhance patriotic festivities with parade marches." 95 In full uniform and bearing their weapons, the corps attended state holiday ceremonies, such as the emperor's birthday, but also Catholic celebrations that either fulfilled an important patriotic role for the monarchy, such as Corpus Christi, or carried a special significance for the region (e.g., festivals of local patron saints). The link between the burgher corps and the Corpus Christi processions was, however, so entrenched that in some regions they were called Prangerschützen (in reference to Prangtag, another name for this holiday). ${ }^{96}$ The regular celebrations fixed in the imperial calendar in the Francis Joseph era symbolized the stabilizing value of monarchic rituals. ${ }^{97}$ The pomp displayed in the Vienna Corpus Christi parade was mirrored, albeit on a smaller scale, in provincial towns, where uniformed army units, state officials, ecclesiastical dignitaries, and local associations all took part in the procession. The order of precedence

\footnotetext{
${ }^{91}$ Wojciech Balus, Krakau zwischen Traditionen und Wegen in die Moderne: zur Geschichte der Architektur und der öffentlichen Grünanlagen im 19. Jahrhundert (Stuttgart, 2003), 89-90.

${ }^{92}$ This was criticized in the newspaper of Masaryk's party: Čas, 30 Aug. 1912, 6-7.

${ }^{93}$ František Spurný, "Mährisch-Schönberg - Eine Domäne der deutschen Industrie," in Kleinstadtbürgertum in der Habsburgermonarchie: 1862-1914, ed. Peter Urbanitsch (Vienna, 2000), 316.

${ }^{94}$ Heinrich Grim, 1630-1908. Chronik des kaiserlich und königlich privilegierten Schützenkorps zu Karlsbad (Carlsbad, 1908), 350. It houses today the Grandhotel Ambassador.

${ }^{95}$ Statuten des k.k. priv. bürgerlichen Schützenkorps in Warnsdorf (Varnsdorf, [1911]), 1.

${ }^{96}$ Harald Dengg and Friederike Zaisberger, eds., Salzburgs Schützen- und Bürgergarden: Landesverteidigung und Brauchtum (Salzburg, 1996), 61.

${ }^{97}$ Daniel Unowsky, The Pomp and Politics of Patriotism: Imperial Celebrations in Habsburg Austria, 1848-1916 (West Lafayette, 2005), 27-30.
} 
visually expressed the hierarchies within urban communities. ${ }^{98}$ Hence, official processions were instances in which the town staged an ordered representation of its social structure. ${ }^{99}$ As such, placements and seating arrangements at Mass were contested among notables. ${ }^{100}$ The civic militias were supposed to contribute to the psychological effects of these ceremonies, increase the impression of stability, and counteract fears and uncertainties through a sense of immutable yearly rhythms.

The salvoes they fired on these festive occasions seem to have been especially important in the sensory experience of local celebrations, along with the sound of church bells. ${ }^{101}$ In St. Johann (near Salzburg), for example, three salvoes were fired for the emperor's birthday: one for the emperor, one for the members of the imperial household, and one for the district officer. ${ }^{102}$ While firing a gun in celebration was not a specifically Austrian custom, the fact that the corps was one of the only civilian institutions allowed to do so conferred great prestige on it. Around the same time, the authorities in Bosnia were forbidding private gunshots during celebrations. ${ }^{103}$ In Dalmatia and Silesia, attempts were also made to regulate the common practice of spontaneous shooting on church holidays as it sometimes led to accidents. ${ }^{104}$ The sound of the salvoes all fired at precisely the same moment was part of the performance. A newspaper report on a celebration in Hallein mentions that the Bürgergarde, "at the main points during the church service, launched the usual discharges with precision." ${ }^{105}$ During the flag dedication ceremony in Eger/Cheb, all sixty Bohemian corps present gave a discharge, although some were more successful than others in firing at exactly the same time. The Luditz/Žlutice chronicle noted: "ours could not have gone better, because it arrived as the public cried loudly 'better, better Luditz,' which we were not little proud of." ${ }^{106}$ Every corps also possessed its own band, which played military marches to accompany the street parades. Several pieces composed especially for local militias attest to the part music played in the corps' lives. ${ }^{107}$

The display of colors in flags and parade uniforms also enhanced the visual appeal of these celebrations. ${ }^{108}$ The uniform was a symbol of bourgeois prestige (made from expensive material, with distinctive colored sashes and buttons), as well as of virile manhood. The cut of nineteenthcentury military uniforms facilitated an erect posture by constricting movements and forcing

\footnotetext{
${ }^{98}$ On the choreography of the 1909 centenary celebrations in Tyrol as symbolizing social order, see Cole, "Für Gott, Kaiser, und Vaterland," 344-45.

${ }^{99}$ For a parallel with May 1st parades in Czechoslovakia, see Roman Krakovsky, Rituel du 1er mai en Tchécoslovaquie 1948-1989 (Paris, 2004).

${ }^{100}$ John Deak, Forging a Multinational State: State Making in Imperial Austria from the Enlightenment to the First World War (Stanford, 2015), 231-32.

${ }^{101}$ On church bells and their meaning, see Claire Morelon, "Sounds of Loss: Church Bells, Place, and Time in the Habsburg Empire during the First World War,” Past \& Present 244 (2019): 195-234.

${ }^{102}$ Salzburger Volksblatt, 20 Aug. 1907, 9.

${ }^{103}$ Risto Pekka Pennanen, "Cannons, Church Bells and Colonial Policies: The Soundscape in Habsburg BosniaHerzegovina" in Cultural Histories of Noise, Sound, and Listening in Europe, 1300-1918, eds. Kirsten Gibson and Ian Biddle (London, 2017), 152-66.

${ }^{104}$ Report on Dalmatia: ÖStA, AVA, MdI, AR, K2154, no. 20543/12, 31 May 1912; on Silesia: no. 10805/03, 10 Mar. 1903.

${ }^{105}$ Salzburger Chronik, 20 Aug. 1906, 4.

${ }^{106}$ Státní okresní archiv Karlovy Vary, Ostrostřelci Žlutice, Kronika ostrostřelců, [11] (in German).

${ }^{107}$ For example: Leopold Sprowacker, Op. 120. Wiener Bürger-Marsch. Dem löblichen I. Wiener BürgerScharfschützen Korps gewidmet. Piano (Vienna, 1906); Anton Absenger and Anton Fridrich, Grenadier-Marsch: zu Ehren des hundertjährigen Jubelfestes des k.k. priv. Bürger-Grenadier-Corps in Graz componiert (Graz, 1895).

${ }^{108}$ On popular participation in military parades in France and Germany, see Jakob Vogel, "Military, Folklore, Eigensinn: Folkloric Militarism in Germany and France, 1871-1914,” Central European History 33 (2000): 487-504.
} 
the wearer to stand upright. ${ }^{109}$ Standing tall was a sign of social distinction and the way bourgeois men carried themselves outwardly was considered as a means of differentiation from the working classes. ${ }^{110}$ The militias' parades displayed a procession of upright citizens, in every sense of the term. Uniforms, which proliferated during this period, also imposed a visual order in cities marking social identity and bearers of authority. The militias' garments were hence not only meaningful for their individual wearer. A public subscription was, for example, raised in Molln (Upper Austria) to replace the civic guard's uniforms as "the people enjoy seeing the civic guard." ${ }^{\prime 11}$ In recalling the prewar civic corps in Waidhofen, a local particularly mentioned their striking appearance: "were they not beautiful, the carnival balls, the celebrations in the town park in which the burgher corps always participated?"112 A newspaper report on the burgher corps parade in honor of the emperor's jubilee in 1908 in Prague, which was attended by burgher corps from all across Bohemia, highlighted the visual appeal of the scene: "The Old Town Square has a tremendously festive and arresting aspect. Flags flying in state and regional colors from the numerous flag poles of the town hall and also from private houses .... Along the ends of the square, rank upon rank of people in festive dress. In addition, the colorful pomp of the uniforms, the blue cloudless sky, the rays of golden sunshine. An indescribably beautiful picture." 13 The mobilization of sensory pleasure invited passive participation on the part of spectators, which united the city around the corps while entrenching social distinctions through its very ordered choreography. ${ }^{114}$

Civic militias also celebrated their own jubilees and flag dedications with large festivities taking place over several days, which actualized the link between the militia and the town's population. In Hallein, the flag dedication in 1907 became the occasion to celebrate "a renewed bond between the individual parts of the patriotic bourgeoisie . . . Civic celebrations [Bürgerfeste] in the truest sense of the word." ${ }^{115}$ The festivities also glorified bourgeois values of work and progress, and the town's illuminations on the eve of the parade included portraits of the founder of the local electricity network and his wife. The chronicle of Grottau/Hrádek nad Nisou insisted on the link between the town community and these celebrations: "The shooters' ancestral games, processions, and competitions helped glamorize the town's celebrations ..... And so it came about that the town's inhabitants felt at one with their shooting brothers, and made their celebrations their own." "116 For the celebration of the burgher corps' 150-year jubilee in Olomouc/Olmütz, "the extremely lavish display of flags, which flapped from most buildings in the city was testament to the participation of all circles of the population in celebrating the burgher corps." ${ }^{117}$ This representation of the whole city standing in unison with the corps was certainly idealized, but these festivities did take over the urban spaces in smaller towns. The chronicle of the 1894 jubilee in the town of Třeboň/Wittingau (Bohemia), for example, recounts the several days of celebration in great detail, from the welcoming of burgher corps from other cities at the train station by the

\footnotetext{
${ }^{109}$ Sarah Jones Weicksel, “To Look Like Men of War: Visual Transformation Narratives of African American Union Soldiers," Clio: Femmes, Genre, Histoire 40, no. 2 (2014): 137-52.

${ }^{110}$ Alain Corbin, Jean-Jacques Courtine, and Georges Vigarello, Histoire du corps (Paris, 2005), 2:370-71.

${ }^{111}$ Linzer Volksblatt, 5 June 1904, 3.

${ }^{112}$ Das Waldviertel, 1954, 93.

${ }^{113}$ Prager Abendblatt, 30 June 1908, 2

${ }^{114}$ On the sensory dimensions of monarchical celebrations in Paris, see Pauline Valade, "Au miroir des sens: Paris, capitale de l'émotion de joie au service de la monarchie (XVIIIe siècle)," Histoire urbaine 54, no. 1 (2019): 55-77.

${ }^{115}$ Volksfreund, 6 July 1907, 1.

${ }^{116}$ Schubert, Geschichte der k. k. priv. Schützen-Gesellschaft in Grottau, 6.

${ }^{117}$ Mährisches Tagblatt, 13 July 1908, 2.
} 
corps' band to the final banquet. The sumptuous decoration of the city's streets for the day of the main parade was meticulously described: the private houses of the different members of the corps on the main town square (in itself a sign of their position in the city) vied for the most elaborate display with flags and drapes in Czech colors, imperial colors, and the colors of the Schwarzenberg family. Other decorations included small trees, pine branches, wreaths, flowers, masts, and banners with messages of welcome or patriotic slogans. "There was no house on the square that was not distinguished by its neat decoration." The final acknowledgments in the chronicle highlighted the hierarchy of participation in the ceremony: first came the noble protector, then the district officer, the visiting militias, the other associations who took part in the procession, and finally "the whole Trrebon citizenry, which took part in our festival with such devotion and taste through the decoration of their houses." 118

The role of women in the celebrations highlights the gendered dynamics at the heart of militia rituals. Women were barred from regular membership, which confirmed the militias' role as an embodiment of bourgeois masculinity. The practice of shooting, of course, already reinforced male camaraderie among the marksmen. ${ }^{119}$ During celebrations, however, prominent women in the community were chosen as flag godmothers. In Engelsberg/ Andělská Hora (Silesia), the entire civic guard came to serenade the "lady" on the eve of the flag dedication. ${ }^{120}$ Young women also played a role in the ceremonies. In Asch/Aš, girls (Festjungfrauen) wearing sashes in the imperial and city colors formed up in front of the church, and six of them carried the flag to be dedicated. ${ }^{121}$ These highly scripted forms of female participation served to confirm the corps' role in representing a form of respectable, chivalric masculinity. As Gabriella Hauch has shown in the case of the 1848 guards, the flag symbolized male protection of the town's women and the ceremony reaffirmed both traditional gender roles. ${ }^{122}$

Festivities were certainly an important part of the corps' lives, as recorded in their chronicles. The very detailed accounts of their activities in the chronicle of the corps in Carlsbad mostly describe social functions: attendance on state or church occasions, shooting contests, and a large number of funerals. ${ }^{123}$ In the smaller towns, in particular, civic militias often acted as de facto burial associations that guaranteed members a respectful bourgeois burial with all the associated pomp (in this case, the presence of the corps in uniform and salvoes). The Domažlice/Taus statutes stipulated that members were obliged to attend the funerals of other members. In Steyr, for example, corps members had the benefit of a third-class hearse for their funerals. ${ }^{124}$ In Cheb/Eger, the burgher corps had its own burial association. ${ }^{125}$ The

\footnotetext{
${ }^{118}$ SOkA Jindřichův Hradec, Sbor ostrostřelců Třeboň, Památní kniha c. k. priv. měštanských ostrostř̌elců.

${ }^{119}$ On the links between weapons and masculinity in Germany, see Ute Frevert, Die kasernierte Nation. Militärdienst und Zivilgesellschaft in Deutschland (Munich, 2001); Dagmar Ellerbrock, "Gun Rights as Privileges of Free Men: Chronology of a Powerful Political Myth of Nineteenth- and Twentieth-Century Germany," in A Man's World? Political Masculinities in Literature and Culture, eds. Kathleen Starck and Birgit Sauer (Newcastle, 2014), 67-79.

${ }^{120}$ Mährisch-Schlesische Presse, 31 Aug. 1910, 4; for similar practices in 1848, see Judson, The Habsburg Empire, 181.

${ }^{121}$ Description from the district officer in Asch/Aš, ÖStA, AVA, MdI, Präs, K2001, no. 7902/14, 23 June 1914. For a similar role of young women dressed in white in Wels during the corps jubilee, see Das interessante Blatt, 25 July 1912 , 10 .

${ }^{122}$ Gabriella Hauch, Frau Biedermeier auf den Barrikaden. Frauenleben in der Wiener Revolution 1848 (Vienna, 1990), 104-5; See also Mirjam Moravcová, “Die tschechischen Frauen im revolutionären Prag 1848/49," in 1848/ 49. Revolutionen in Ostmitteleuropa, eds. Rudolf Jaworski and Robert Luft (Munich, 1996), 75-96.

${ }^{123}$ Grim, 1630-1908. Chronik des kaiserlich und königlich privilegierten Schützenkorps zu Karlsbad.

${ }^{124}$ Chronik des k.k. priv. uniformierten bewaffneten Bürger-Corps der l. f. Stadt Steyr, 223.

${ }^{125}$ Jitka Chmelíková, Pohřební spolek sboru ostrostřelců Cheb [finding aid], SOkA Cheb, 2003.
} 
appeal of a decent, free funeral would have been an important enticement to join one of the local corps. ${ }^{126}$ Imperial authorities even worried that the provision of a free funeral stipulated in the statutes of the Prachatitz/Prachatice corps threatened to divert it from its main purpose. ${ }^{127}$ Appropriate funerals were not an incidental part of the militias' mission, but instead, in identifying their members as belonging to the respectable community of a town, reflected their role in perpetuating a social order that would be completely turned upside down after 1914.

\section{Wartime and Postwar Disorder}

When World War I broke out in 1914, many members of the police forces left for the front. The Austrian state and municipalities all over the empire needed dependable citizens to maintain law and order. The burgher corps were mobilized as reserve forces, patrolling the streets and standing guard outside public buildings in many cities. Furthermore, numerous calls to join the existing or newly formed civic militias appeared on street corners and in newspapers. For example, in August 1914, the municipality of Brünn/Brno issued a public notice explaining that policing duties would be undertaken by "patriotically minded men" who had volunteered to join a militia (Schützenwehr), and by the local burgher corps. Members of the burgher corps were supposed to wear their uniform, and members of the new militia a yellow-and-black armband displaying the city arms of Brünn/Brno. ${ }^{128}$ In Czernowitz/ Cernăuți/Chernitsvi in Bukovina, a civic militia of 240 men had the task of "maintaining order and safety in the city, and safeguarding the goods that the [soldiers] have left us to protect." They were not uniformed, but they wore a yellow-and-black armband. Membership was reserved for the town's citizens or landowners, and its youth group for secondary school students. ${ }^{129}$ In Nowy Sacz, the civic guard was made up of both volunteers and men forced to enroll. ${ }^{130}$ In Lemberg/Lwów/L'viv, the municipality created a municipal civic guard (Miejska straż obywatelska) and a municipal militia (milicja miejska) of volunteers to preserve law and order during the Russian occupation. ${ }^{131}$ The numbers of burgher corps and veterans' association members also swelled in Graz and its surroundings in the early months of the war. The creation of other militias in the city and its suburbs was a result of local initiatives supported by state authorities. ${ }^{132}$

The formation process of civilian units for managing public order varied locally and relied on existing structures. In Bohemia, for example, a memorandum from the governor to all district officers in early August encouraged the organization of volunteers to support the police forces. This document referred to several associations that might be relied on: veterans' associations,

\footnotetext{
${ }^{126}$ NA, MV/R, ka 1756, sig. 21, 27313/05, 13 June 1905.

${ }^{127}$ On burial clubs and the social significance of funerals in the nineteenth century, see Thomas Laqueur, The Work of the Dead: A Cultural History of Mortal Remains (Princeton, 2015), 312-36.

${ }^{128}$ See the bilingual public announcement poster (16 Aug. 1914), Österreichische Nationalbibliothek (ÖNB, Austrian National Library), Öffentliche Wachen - Kundmachung - Brünn Z. 2487 präs, accessed 31 Aug. 2019, http://www.bildarchivaustria.at/Preview/14253037.jpg.

${ }^{129}$ Bukowinaer Post, 2 Aug. 1914, 1-2.

${ }^{130}$ See the regulations for the civic guard in Nowy Sącz (20 Aug. 1914), ÖNB, Öffentliche Militz - Regelungen - NeuSandez, accessed 31 Aug. 2019, http://www.bildarchivaustria.at/Preview/14275286.jpg.

${ }^{131}$ Henryka Kramarz, Samorzád Lwowa $w$ czasie perwsziej wojny światowej i jego rola w życiu miasta [Lwów’s municipal government during the First World War and its role in the life of the city] (Cracow, 1994), 38; and Kurjer Lwowski, 1 Sept. 1914, 1-2; 8 Sept. 1914, 3.

${ }^{132}$ Bernhard Thonhofer, Graz 1914: der Volkskrieg auf der Straße (Vienna, 2018), 375-80.
} 
firemen, and German and Czech gymnastics associations (Turnvereine and Sokols). The list reveals who the Austrian state considered potential allies in civil society to maintain order. Nationalist associations were here placed on equal footing with patriotic associations. The goal was to "ensure the safety of person and property" by turning to the "elements of order at their disposal." In municipalities where no previous association existed, "reliable individuals" could be drawn upon. The governor did not give precise instructions as long as members wore a distinctive sign. ${ }^{133}$ In Aussig/Ustí nad Labem, the three-hundred-man volunteer watch corps was formed of firemen, members of veterans' and gymnastics associations, and other "reliable men." ${ }^{\text {"34 }}$ From 21 August, they were patrolling the streets wearing yellow-and-black armbands. A report mentioned that in every municipality in the Prague vicinity many men had volunteered for police work, especially from the ranks of the firemen and Sokols. ${ }^{135}$ Similar measures were taken in Moravia: in Prostějov/Prossnitz, for example, a civic defense (občanská ochrana) corps of volunteer "trustworthy inhabitants" was constituted. ${ }^{136}$ In a city like Marburg/Maribor, where there had been no burgher corps before the war, the rhetoric around the creation of a militia (Bürgerwehr) still referred to the historical tradition of civilian defense against the Turks and taking up arms in 1848. In its inaugural meeting, the maintenance of peace and order was framed as the "duty of the citizens who stayed behind," a counterpart to the soldiers' fight for the empire. ${ }^{137}$

The militias patrolled at night and during the day to protect private and public property. The burgher corps in Prague and in Vienna carried out garrison duties as watchmen at locations usually guarded by the military, such as military warehouses, prisons, and tax offices. ${ }^{138}$ Their task was also to secure the territory against potential enemies. In early August 1914 in Domažlice/Taus in Western Bohemia, the district officer asked the burgher corps to keep armed watch at night to potentially intercept French cars carrying gold to Russia. ${ }^{139}$ The corps' chronicle reported, somewhat disappointedly, that no such cars had appeared. ${ }^{140}$ Sometimes, overzealous watchmen making use of their firearms too readily led to clashes with the public. In Graz, a member of the burgher corps wounded with his bayonet a man who had reached in his pocket to offer him a cigarette. ${ }^{141}$ The atmosphere of heightened suspicion against imagined or real enemies, which formed part of the mental mobilization for war, was at the heart of this rise in volunteer policing. ${ }^{142}$ But, as more and more men were sent to the front, militia men were also accused of shirking military service. Their activity on the home front became more suspect in a wartime moral economy that

\footnotetext{
${ }^{133}$ Memorandum from the Bohemian governor, NA, Prezídium českého místodržitelství (Presidium of the Bohemian Governor's Office, PM) 1911-1920, ka 5051, sig. 8/1/92/19, no. 17366, 8 Aug. 1914.

${ }^{134}$ NA, PM 1911-1920, ka 5051, sig. 8/1/92/19, no. 17366, report from the district office in Aussig/Usti, 21 Aug. 1914.

${ }^{135}$ NA, PM 1911-1920, ka 5051, sig. 8/1/92/19, no. 17366, report from the district office in Král. Vinohrady, 31 Aug. 1914.

${ }^{136}$ Národní listy, 28 Dec. 1914, 2.

${ }^{137}$ Marburger Zeitung, 19 Dec. 1914, 14.

${ }^{138}$ Venkov, 17 Aug. 1914, 3; see also a letter from the Military Command in Vienna praising the prison watch of the Deutschmeister-Schützenkorps in Vienna, ÖStA, KA, Militärische Nachlässe, B/1229, Franz von Prati, 4 May 1916.

${ }^{139}$ In Germany, the rumors of these French "gold cars" led armed volunteers to stop, and even shoot at, passing cars, see Sven Oliver Müller, Die Nation als Waffe und Vorstellung: Deutschland und Grossbritanien im Ersten Weltkrieg (Göttingen, 2002), 67-69. On the spy fever, see Florian Altenhöner, Kommunikation und Kontrolle. Gerüchte und städtische Öffentlichkeiten in Berlin und London 1914-1918 (Munich, 2008), 192-93.

${ }^{140}$ Státní okresní archiv Domažlice, archiv Domažlice, Ostrostř. Domažlice, Kronika sboru ostrostřelců.

${ }^{141}$ For this and other examples, see Thonhofer, Graz 1914, 382-83.

${ }^{142}$ On civilian vigilantism in the U.S. wartime context, see Christopher Capozzola, Uncle Sam Wants You: World War I and the Making of the Modern American Citizen (Oxford, 2008), 117-43.
} 
stigmatized "shirkers" (those avoiding military service) and "profiteers" (those driving up prices) for not participating in the common sacrifice. ${ }^{143}$ The accusations against the Deutschmeister-Schützenkorps in Vienna exemplify the ambiguities of home-front civilian service. ${ }^{144}$ Several letters denouncing the cowardice of corps members or accusing Jews of having taken over the corps to avoid military service were sent to the commander. One of them signed by enlisted soldiers complained that men in the corps had not yet been sent to the trenches: it warned that "justice alone leads to victory." 145 Another declared that the corps' offices had been a "Jewish nest" since the beginning of the war, linking the corps to the supposed shirking of military duties. ${ }^{146}$ The commander used his weapon against a civilian who had insulted the corps in an exchange in a coffeehouse. In reference to the Tyrolean Standschützen, the man had declared: "They are not shirkers like you sharpshooters (Schützen)! Go to the trenches, too, instead of keeping watch here in Vienna!" In his description of the incident, the commander insisted on his defense of the corps' honor against insults and on the many sacrifices made by corps members during their service in Vienna. He lamented the current "animosity against every male who is not in the field," which could lead an "academically educated man" to "insult patriotic men." 147 In Prague, a shoemaker was condemned to three days' arrest because he had poked fun at the burgher corps in a pub, walking around with a broom on his shoulder and shouting: "that's how the sharpshooters (scharfschützové) dance in front of the emperor!" 148

The different formations that had been created everywhere in both the Austrian and Hungarian halves of the monarchy evolved during the conflict. Their makeup changed significantly as the numbers of men recruited for active military service increased. By 1915, 180 of the 300 men of the Schützenwehr formed a year earlier in Olmütz/Olomouc had already been called up. The militia issued an announcement to recruit new volunteers, appealing to their patriotism and public spirit. ${ }^{149}$ The corps' shooting courses during the war often became preparation for upcoming experience on the front. A poster enjoining young people to enroll in the Jungschützenkorps in Vienna emphasized the values of home-front war activism: "Participate in arms, show that you are good citizens." ${ }^{150}$ Moreover, many corps companies were gradually sent to the front. On the departure of a company of the Graz burgher corps in July 1915, the governor's speech mentioned that the corps was thereby leaving its traditional function of defending the city behind. ${ }^{151}$ The new and old

\footnotetext{
${ }^{143}$ John Horne, "Public Opinion and Politics," in A Companion to World War I, ed. John Horne (Chichester, 2010), 283.

${ }^{144}$ For a comparable phenomenon of civilian volunteers in England, see Laura Ugolini, Civvies: Middle-Class Men on the English Home Front, 1914-1918 (Manchester, 2013), 157-81.

${ }^{145}$ Anonymous letter ÖStA, KA, Militärische Nachlässe, B/1229, Franz von Prati, 4 Aug. 1915; on antisemitic attacks against Jewish soldiers during the war, see Marsha Rozenblit, Reconstructing a National Identity: The Jews of Habsburg Austria during World War I (Oxford, 2001), 93-94.

${ }^{146}$ Anonymous letter, ÖStA, KA, Militärische Nachlässe, B/1229, Franz von Prati, 20 Jan. 1915.

${ }^{147}$ Declaration by the corps commander Franz von Prati, ÖStA, KA, Militärische Nachlässe, B/1229, Franz von Prati, 1 July 1915.

${ }^{148}$ Report from the Police Headquarters in Prague, NA, PM 1911-1920, ka 5057, sig. 8/1/92/19, no. 1492, no. 1184, 7 Jan. 1915.

${ }^{149}$ Deutsches Nordmährerblatt, 11 June 1915, 5.

${ }^{150}$ See a recruitment poster of the Vienna Jungschützenkorps, Wienbibliothek, "Aufruf an die patriotische Jugend zum Eintritte in das Jungschützenkorps!” [c. 1916], accessed 5 Sept. 2019, https://www.digital.wienbibliothek.at/ wbrobv/content/pageview/472630.

${ }^{151}$ See the speech by the Governor of Styria, 30 July 1915, Steirisches Landesarchiv (Styrian Regional Archives, Graz), Miszellen, Sachgruppenreihe, Karton 338.
} 
civic guards thus became gradually less relevant as home-front forces and some of them were even dissolved in 1915 or 1916. Similar formations in World War I France also had a shortlived existence because the state did not really know how to manage them effectively. ${ }^{152}$

Nevertheless, the war experience was transformative for civic militias. More men, common citizens, were drawn into the business of policing and protection. Appeals to increase their numbers of volunteers broadened the traditional base of the different corps, such as the Vienna Bürger-Scharfschützenkorps. The corps in Prague organized a collection to provide equipment for young men from less well-off backgrounds who had volunteered to join their youth guard. ${ }^{153}$ The rhetoric often still referred to the city's burghers (and a glorious past, such as resistance to the Turks), but also included the wartime message of sacrifice on the home front, which had to equal that on the front. ${ }^{154}$ An article in the Catholic Reichspost praised the spirit of sacrifice for the fatherland that united Upper Austrian volunteers "whatever estate they might belong to." ${ }^{155}$ Purseigle, in his examination of the Voluntary Training Corps in England during the war, observed how a similar shift in the recruitment base of volunteer forces threatened to undermine the legitimacy of the bourgeois groups who viewed themselves as the only repository of civilian vigilantism. ${ }^{156}$

The concept of civic home defense was quickly revived at the end of the war in 1918 when the fall of the empire created a vacuum in terms of the protection of private property. The collapse of state authority in a context of enormous food shortages increased the risk of theft or even mass looting (of factories, food provisioning centers, and other locations). In Aussig/Ústí nad Labem, for example, large stocks of food in factories and military depots were systematically plundered in early November. The newly created civic militia contained the crowds with difficulty, and a workers' militia was constituted overnight to help them. ${ }^{157}$ In Teplice/ Teplitz, the civic guard shot at a crowd ransacking food in an inn. ${ }^{158}$ In November 1918, towns and municipalities across the former empire organized local civic militias. ${ }^{159}$ In Gorlice, for example, a civic guard was formed to safeguard public order. ${ }^{160}$ Following robberies, a Bürgerwehr "from all parts of the population" was created in Friedland/Frýdland to patrol the streets. ${ }^{161}$ As deserters and demobilized soldiers roamed the countryside, peasants protected their supplies with weapons, and towns armed themselves to prevent looting. ${ }^{162}$ A Viennese newspaper reflected on the fact that the proliferation of these "guards" did not necessarily make the city safer but fostered instead more dangerous

\footnotetext{
${ }^{152}$ Arnaud-Dominique Houte, "Policiers de bonne volonté? L'impossible constitution d'une garde civile en France (1913-1920)," Vingtième Siècle 118, no. 2 (2013): 159-70.

${ }^{153}$ Letter from the commander to the Prague Police Headquarters, NA, Prezídium policejního ředitelství Praha (Presidium of the Prague Police Headquarters, PP) 1916-1920, ka 2908, sig. B 41/II, no. 3930, 20 Apr. 1917.

${ }^{154}$ See a recruitment poster of the Vienna Bürger-Scharfchützenkorps, Wienbibliothek, "Aufruf an die Wiener Bevölkerung!” [c. 1914], accessed 11 Dec. 2019, https://www.digital.wienbibliothek.at/wbrobv/content/pageview/ 472626.

${ }^{155}$ Reichspost, 27 June 1915, 10.

${ }^{156}$ Pierre Purseigle, Mobilisation, sacrifice et citoyenneté: Angleterre-France, 1900-1918 (Paris, 2013), 352-60.

${ }^{157}$ Prager Abendblatt, 4 Nov. 1918, 4.

${ }^{158}$ Prager Abendblatt, 7 Nov. 1918, 5.

${ }^{159}$ On early self-defense groups in Austria, see David Clay Large, The Politics of Law and Order: A History of the Bavarian Einwohnerwehr 1918-1921 (Philadelphia, 1980), 54-55.

${ }^{160}$ Kamil Ruszała, Wielka Wojna $w$ małym mieśce: Gorlice $w$ latach 1914-1918 [The Great War in a small town: Gorlice in the years 1914-1918] (Cracow, 2015), 209-10.

${ }^{161}$ Also in Leipa. Reichenberger Zeitung, 10 Nov. 1918, 2.

${ }^{162}$ On deserters, see Jakub Beneš, “The Green Cadres and the Collapse of Austria-Hungary in 1918," Past \& Present 236, no. 1 (2017): 207-41.
} 
conditions: "we have a Volkswehr, a red guard, a Stadtwehr: the students have a student guard and the burghers a Bürgerwehr."

In creating these civilian armed groups, municipalities often relied on existing home defense associations. The "old" burgher corps were sometimes called on to patrol, as was the case in Prague, or asked to coordinate efforts to mobilize civilians, as in Reichenberg/Liberec. ${ }^{164}$ In Graz, the burgher corps changed its name to "city defense" (Stadtwehr) and recruited new volunteers. ${ }^{165}$ In the Czech context, the national guards formed to maintain peace and order often stemmed from the Sokol gymnastics association. A call to join the National Guard (národní stráž) that had spontaneously formed to protect "public order, civic rights, and the property of the young state" was signed by the Sokols, the union of Czechoslovak students, and the workers' gymnastics association. The formation invited returning soldiers to enlist, and was turned into a more permanent structure for volunteers who performed guard duties for the first few months of the republic. ${ }^{166}$ Appeals to the members of shooting clubs to carry out patrols were also published in the Czech press. ${ }^{167}$ Spontaneous formations also emerged in this period: in Březnice, an armed civic guard composed of eighty "reliable citizens" was created in February 1919 after theft had increased in the city. ${ }^{168}$

The new civic defense units set up in November 1918 against disorder were appealing to a much broader social base than prewar militias. For example, in Znojmo/Znaim in Southern Moravia "all men of eighteen to forty-two years of age currently residing within the city limits" were obliged to report. ${ }^{169}$ In Krems, the home defense incorporated all men, "workers and bourgeois," who had resided in the city for more than fifteen days for the "protection of Krems and its surroundings." ${ }^{170}$ Some Bürgerwehren even changed their name to Gemeindewehren to signal a greater degree of social inclusivity. ${ }^{171}$ The required length of residence was also significantly lowered. We can see here a shift from 1914 to 1918 in the recruitment of the civic militias. The war had changed notions of citizenship, as so many men had participated in battle as soldiers. The conception of the entitlements associated with citizenship had also undergone a major transformation through the war experience. In Czernowitz/Cernăuți/Chernitsvi, the call appealed to "civic spirit" but also mentioned that some men would be compensated. ${ }^{172}$

Former soldiers were also recruited locally into Volkswehr (popular defense) units to maintain peace and order. The makeup, level of discipline, and activities of these units varied greatly across Austria. Outside the larger cities, they did not have a specific political affiliation. ${ }^{173}$ The ephemeral German Bohemian administration set guidelines for the operation of the Volkswehr, which were to be created by district authorities, municipalities, or national councils, and financed by them. Their first task was "the maintenance of order, of personal safety, of the freedom acquired, of private property, and . . state property." ${ }^{\prime 74} \mathrm{~A}$

\footnotetext{
${ }^{163}$ Wiener Sonn- und Montags-Zeitung, 18 Nov. 1918, 2.

${ }^{164}$ On the Prague burgher corps as national guard, see Národní politika, 25 Nov. 1918, 1; on Reichenberg, see: Prager Abendblatt, 4 Nov. 1918, 4.

${ }^{165}$ Grazer Tagblatt, 6 Nov. 1918, 10; 26 Nov. 1918, 10.

${ }^{166}$ Národní politika, 9 Nov. 1918, 2; 28 Dec. 1918, 2.

${ }^{167}$ Národní politika, 31 Oct. 1918, 2.

${ }^{168}$ Národní listy, 21 Feb. 1919, 4.

${ }^{169}$ Znaimer Tagblatt, 9 Nov. 1918, 3.

${ }^{170}$ Österreichische Land-Zeitung, 9 Nov. 1918, 3-4.

${ }^{171}$ Large, The Politics of Law and Order, 56.

${ }^{172}$ Czernowitzer Allgemeine Zeitung, 7 Nov. 1918, 3.

${ }^{173}$ See Francis Carsten, Revolution in Central Europe: 1918-1919 (London, 1972), 78-107.

${ }^{174}$ ÖStA, Archiv der Republik, Oberste Behörden, Deutschböhmische Landesregierung, K129/29, "Vorläufige Richtlinien für die Aufstellung der deutschösterreichischen Volkswehr," Nov. 1918.
} 
recruitment drive in the district of Grulich/Králíky mentioned pay of six crowns a day and insisted on the fact that the men would stay home: "you will protect your own property and that of your relatives and co-citizens." ${ }^{175}$ This entrusting of town dwellers' safety to the Volkswehr units was expensive and might be uncertain if unreliable elements joined their ranks. A play satirized the Volkswehr's actions in a Western Bohemian town, showing men stealing coal and shirking their guard duties to the point where the "propertied section of the population" felt relieved when Czech troops entered the town. ${ }^{176}$

In the first months after regime change, the primary concern and mobilizing factor was the preservation of property rather than national hatreds. Even in Carinthia, where the Volkswehr subsequently fought against Yugoslav troops, the motivation for the initial mobilization was the protection of home and property against disorder. ${ }^{177}$ Similarly, in Bohemian towns with a German-speaking majority, local defense units sometimes tried to remove the Czech army with violence, ${ }^{178}$ but the call from Reichenberg/Liberec emphasized the protection of "home, house, herd, and family" not only against an external enemy but also from "dishonest elements" and "excesses." 179

However, with the disappearance of a supranational patriotic ethos, the postwar militias promoted a more national conception of homeland defense. The Viennese burgher corps published a call to join their ranks that restricted admission to "respectable fellow German citizens over seventeen." The slogan was: "Protect German Vienna! Protection of property and goods, hearth, and family for all fellow citizens." The corps' emphasis on social exclusivity was replaced with national exclusivity, while the rhetoric of "order" remained unchanged: "peace and order is more than ever necessary in our home city." ${ }^{\prime 80}$ The Czech Sokols' patrols echoed this motto of "order": "'peace and order' was the command," according to the chronicler in Mladá Boleslav/Jungbunzlau. ${ }^{181}$ In Prague, where the Sokol watchmen's purpose and scope of action were not clearly defined, one squad recalled having acted mainly with "order, peace, and the good of our young republic" in mind. ${ }^{182}$ The Sokols in Písek, acting on the orders of the local authorities, helped to prevent looting in shops during food riots in November 1918. The day and night watch formed in the following weeks "for the continuing maintenance of peace and order in the town" were led by a uniformed Sokol. Many returning soldiers joined their ranks. ${ }^{183}$ The distinction between volunteer civilians and paid, state-sanctioned soldiers in this period was not clear-cut. Sokol units in Southern Bohemia patrolled train stations and the border and later joined the National Guard, receiving some financial payment for their services. ${ }^{184}$ Yet, another chronicle pointed out that, at a time when the military sometimes recruited suspicious

\footnotetext{
${ }^{175}$ Josef Brauner, Erster-Weltkriegs-Tagebuch aus der böhmischen Provinz Aufschreibungen aus Grulich der Kriegsjahre 1914 bis 1918 und danach 1919 bis 1921 (Leipzig, 2016).

${ }^{176}$ Written by the school director in Carlsbad: Josef Hofmann, Die Volkswehr in Westböhmen (Cheb, 1921); see also a call to the "propertied population" to make donations for the Bürgerwehr in Znojmo/Znaim, Znaimer Tagblatt, 14 Nov. 1918, 2.

${ }^{177}$ See Tamás Révész, "For the 'freedom and unity' of Carinthia? New perspectives on the military remobilization in the Carinthian borderland war (1918-1919)," First World War Studies 7, no. 3 (2016): 276.

${ }^{178}$ For example, in Brüx/Most where they shot from the church tower: Prager Tagblatt, 29 Nov. 1918, 1.

${ }^{179}$ Reichenberger Zeitung, 3 Nov. 1918, 1.

${ }^{180}$ Poster ÖNB, "Deutsche Mitbürger - Schutz dem deutschen Wien,” 1918, accessed 4 Sept. 2019, http://www. bildarchivaustria.at/Preview/15827741.jpg.

${ }^{181}$ SOkA Mladá Boleslav, Sokol - tělocvičná jednota Mladá Boleslav, Pamětní kniha Sokola v Mladé Boleslavi, 305.

${ }^{182}$ NA, Sokol Pražský, ka 57, XX 4, "Stručné paměti o činnosti sokolské stráže na nádraží drahy severo-západní."

${ }^{183}$ See the Sokol chronicle, SOkA Písek, Pamětní kniha Sokola v Písku, 176.

${ }^{184}$ SOkA Jindřichův Hradec, Kronika tělovýchovné jednoty Sokol v Chlumě u Třeboně, 38-39.
} 
elements, it was important to have "reliable people devoted to the government" who in some cases could even provide protection "against the dishonest elements." 185 The paramilitary components of gymnastics associations like the Sokols came very much to the fore in the immediate postwar period, with a rhetoric emphasizing law and order and loyalty to the state similar to that used by the burgher corps in the prewar period.

The Bohemian burgher corps sometimes adapted to the new circumstances. The three units of the Prague burgher corps were quickly mobilized to serve as patrols and renamed the Prague National Militia (Národní milice). Their mission in the interwar period closely resembled that of the prewar burgher corps: "fostering the state idea"-Czechoslovak this time-protection of property, and defense against "internal and external enemies." ${ }^{186}$ In Domažlice/Taus, after the confusion of 1918 when the shooting range was briefly ceded to the Sokol, the corps regained its building in 1919 and simply changed its name to National Militia (Národní milice) in $1921 .^{187}$ Burgher corps in German-speaking areas became suspect, for example in Zlabings/Slavonice, where the Czechoslovak army seized all weapons in private possession on 18 November 1918, including the shooting society's rifles. ${ }^{188}$ In the 1920 s, the separation of Czech and German shooting associations was confirmed by separate official statutes. ${ }^{189}$

In postwar Austria, the civic militias formed the basis of the Heimwehr movement of the 1920s and 1930s. ${ }^{190}$ However, the militias that formed in the immediate aftermath of state collapse were not simply "counterrevolutionary" forces. Considering paramilitary groups as mainly a reaction to military defeat and the Bolshevik Revolution ignores the very local context of their emergence, the "small fatherlands" they aimed to defend, and the continuity with prewar formations. ${ }^{191}$ Postwar militias went beyond the radical right-wing groups concerned with ethnic borders and red uprisings and financed by international conservatives. ${ }^{192}$ They were also shaped by conceptions of armed local defense prevalent before the war, mass participation in wartime service having reinforced the previous traditions of civilians in arms. ${ }^{193}$ The collapse of state authority meant

\footnotetext{
${ }^{185}$ SOkA Mladá Boleslav, Sokol - tělocvičná jednota Mladá Boleslav, Pamětní kniha Sokola v Mladé Boleslavi, 309.

${ }^{186}$ Večerník Národních listů, 14 Sept. 1938, 4. On the name change, see: Národní politika, 25 Nov. 1918, 1.

${ }^{187}$ SOkA Domažlice, Archiv Domažlice, Ostrostř. Domažlice, Kronika sboru ostrostřelců. It seems that the burgher corps in Jičín/Jitschin also became a national militia in 1919 and then National Guard in 1930, see the description of the fund of the Národní garda 4. krajského města Jičín in the Státní okresní archiv Jičín, accessed 4 Sept. 2019, http:// www.badatelna.eu/fond/88407.

${ }^{188}$ Interpellation des Abgeordneten Dr. Emmerich Radda und Genossen an den Minister des Innern betreffend die Beschlagnahme von Waffen. Poslanecká sněmovna N. S. R. Č. 19212856.30 June 1921, accessed 30 Jan. 2020, http:// www.psp.cz/eknih/1920ns/ps/tisky/t2856_00.htm.

${ }^{189}$ Ludomír Kocourek (Státní okresní archive Most), Spolek ostrostrelcủ Most: Inventář [Sharpshooters' association Most: Finding aid] (Most, 1975), 2-3. On armed organizations in interwar Czechoslovakia, see Miloslav Čaplovič, Branné organizácie $v$ Československu 1918-1939 (so zretelom na Slovensko) [Armed organizations in Czechoslovakia 1918-1939 (with a focus on Slovakia)] (Bratislava, 2001).

${ }^{190}$ On the Heimwehr, see C. Earl Edmondson, The Heimwehr and Austrian Politics 1918-1936 (Athens, GA, 1977); Walter Wiltschegg, Die Heimwehr: eine unwiderstehliche Volksbewegung? (Munich, 1985).

${ }^{191}$ On paramilitarism and violence after the war, see Gerwarth, The Vanquished; Gerwarth and Horne, War in Peace; Jochen Böhler, Civil War in Central Europe, 1918-1921: The Reconstruction of Poland (Oxford, 2018); Jochen Böhler, Włodzimierz Borodziej, and Joachim von Puttkamer, eds., Legacies of Violence: Eastern Europe’s First World War (Munich, 2014); Ota Konrád, Rudolf Kučera, Cesty z apokalypsy: Fyzické násilí v pádu a obnově střední Evropy 1914-1922 [Ways out of the apocalypse: Physical violence in the fall and renewal of Central Europe, 1914-1922] (Prague, 2018).

${ }^{192}$ John Lauridsen has argued for a stronger emphasis on the Austrian social context in the analysis of the Heimwehr, see John T. Lauridsen, Nazism and the Radical Right in Austria, 1918-1934 (Copenhagen, 2007), $123-24$.

${ }^{193}$ On continuity in Tyrol, see Jason Engle, A Legion of Legacy: Tyrolean Militarism, Catholicism, and the Heimwehr Movement (Ph.D. dissertation, University of Mississippi, 2017).
} 
that local administrations often delegated security duties to armed citizens: this authority transfer was especially sanctioned in small communities and meant that by the early 1920 s many military weapons were still in private hands. ${ }^{194}$ The militias' growing anti-Social Democrat stance (from 1919 to 1920) can also be viewed as being in continuity with prewar concerns over the upheaval of social order. The plethora of militias that flourished in the immediate aftermath of World War I did not hence constitute a geographically homogenous or ideologically coherent movement. ${ }^{195}$ Rather, these civilian defense units formed a cluster of small local groups fighting to uphold social and public order in their own town or municipality.

\section{Conclusion}

Regarded then and now as quaint, irrelevant organizations, the urban civic militias shed light on conceptions of patriotism and citizenship in the late Habsburg Empire. Through their promotion of shooting as a patriotic duty, they participated in the societal militarization of Austria-Hungary. The last years before World War I, which saw heightened domestic tensions combined with the growing chances of a conflict with Russia, gave a new impulse to civilian armed formations. But their main significance was not really their military role. Just as their predecessors, they embodied the link between local citizenship and the notion of bearing arms. Their renewed growth at the turn of the century coincided with a time when the contours of citizenship were being redefined and hotly contested among calls for the enlargement of the franchise. The militias also represented the articulation of different levels of patriotism (urban, national, and imperial) in Habsburg Austria. In the case of the Czech shooting corps, prewar Habsburg patriotism was simply transferred to the Czechoslovak state.

At the local level, civic militias were a concrete expression of social order and hierarchy in medium-sized towns. In their rituals and practice of shooting, the burgher corps conveyed a certain image of bourgeois respectability, which came especially under threat with the rise of Social Democracy. Christian Social mayor Karl Lueger tried to transform the Viennese sharp shooting corps into a form of armed vigilante group to foster public safety. The militias reaffirmed a sense of close, exclusive, petty bourgeois community, which was particularly significant in the context of the growing influence of the workers' movement. This confrontation was also spatial and manifested itself in the urban space: the orderly religious and state processions reflected this idealized version of the social world, while the May 1st demonstrations constituted a challenge to the spatial dominance of established burghers.

The study of Habsburg civic militias also puts the paramilitarism of the immediate postwar in a new light. The militias were called upon to perform their duty in wartime and formed the basis of postwar civilian involvement in the management of law and order. The armed groups created in the aftermath of the war were not only forces of counterrevolution but also local self-defense units upholding the shaken foundations of social order. Violence in this context does not seem

\footnotetext{
${ }^{194}$ See, for example, the documents on disarmament: Oberösterreichisches Landesarchiv, Archiv der k. k. Statthalterei, Allgemeine Reihe, K3479, sig. IX/25, no. 22849/1921, 12 June 1921, Interior Ministry to the regional government in Upper Austria. See also a request for weapons from a factory owner to prevent burglaries, ibid., no. 3376/1920, 11 Feb. 1920, Firm Excelsior in Weyer to the regional government; in Styria, the Social Democrat Arbeiterwille complained about the continued distribution of weapons to local civic militias once the postwar conditions had receded, Arbeiterwille, 7 June 1919, 1.

${ }^{195}$ On the social background of paramilitary groups in Hungary, see Béla Bodó, "The White Terror in Hungary, 1919-1921: The Social Worlds of Paramilitary Groups," Austrian History Yearbook 42 (2011): 133-63.
} 
to be the only relevant benchmark by which to approach the relationship between weapons and political participation. Other less violent forms of vigilantism still set the boundaries for who the legitimate defenders of the community were. It was therefore not only the culture of defeat or anti-Bolshevism that determined postwar mobilization but also an extended conception of citizenship and participation in the maintenance of social order. The legacies of this general taking-up of arms shaped political participation in the interwar period. The concept of citizenship provides a link between the pre- and postwar forms of armed volunteerism if understood not just as a legal category of belonging but also as the active quality of "reliable" men, those who could be trusted with arms to act as forces of "order."

Claire Morelon is ERC postdoctoral researcher at the University of Padova. She received her Ph.D. from the University of Birmingham and the Institut d'Études Politiques (Paris) and was then Junior Research Fellow at the Queen's College, University of Oxford. She is currently preparing her first monograph for publication, entitled Streetscapes of War and Revolution: Prague, 1914-1920. Her publications include "Sounds of Loss: Church Bells, Place, and Time in the Habsburg Empire during the First World War" (Past \& Present [2019]) and the edited volume Embers of Empire: Continuity and Rupture in the Habsburg Successor States after 1918 (Berghahn, 2018). 